أثر تجربة السجن في شعر ابن زيدون وابن عمار

م.د شيماء هاتو فعل ، جامعة البصرة ، كلية التربية ، قسم اللغة العربية

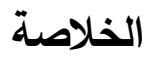

تتولد لاى الإنسان إزاء تجارب الحياة مواقف متباينة تحدد المسارات التي يخوض غمارها ، وتجربـة

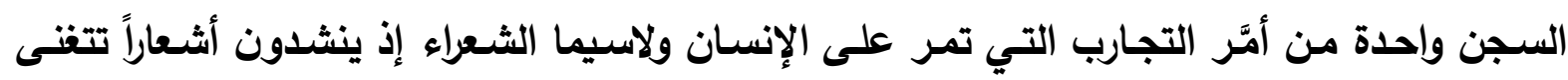

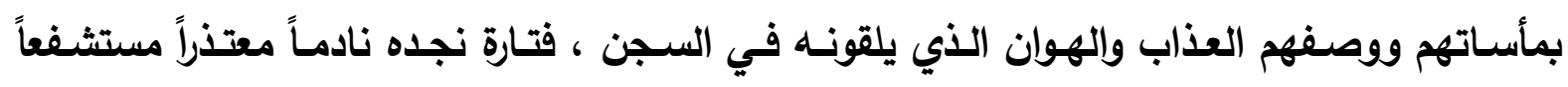

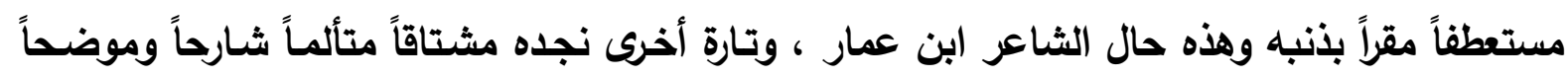

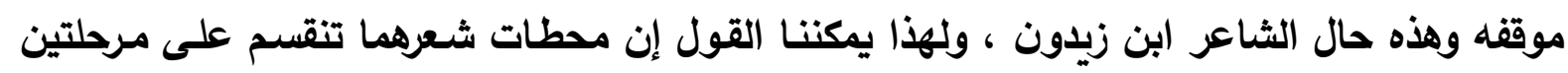

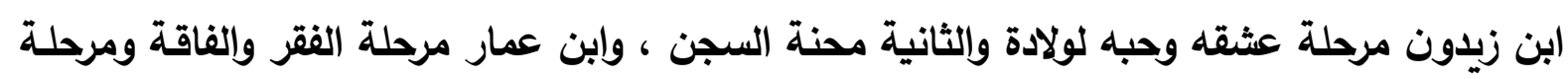

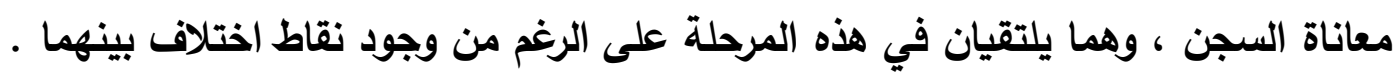

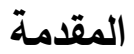

تتنوع الموضوعات التي ينظم فيها الثعراء ، وغالباً ما تتاخل هذه الموضوعات مـع بعضها وبحثنا

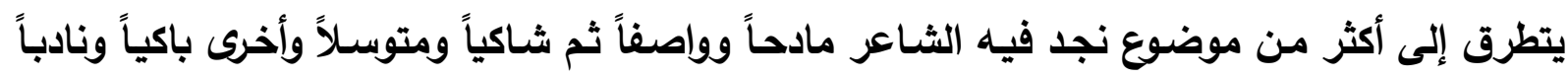
حظَّّهُ وزوال نعمته ، ومما لاثك فيه إن الثاعر يجد في الثعر وسيلته التي تفصح عن أحزانه وأفراحه

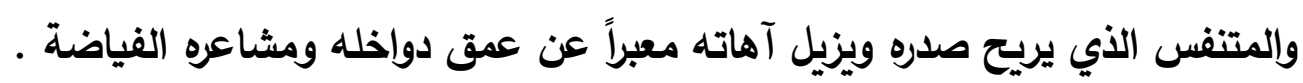

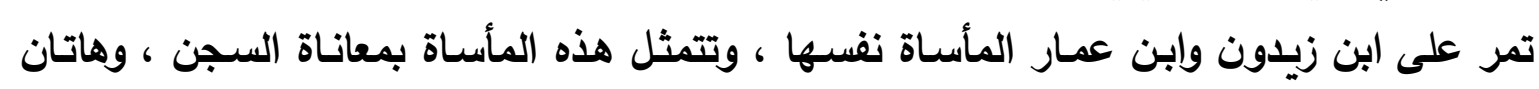

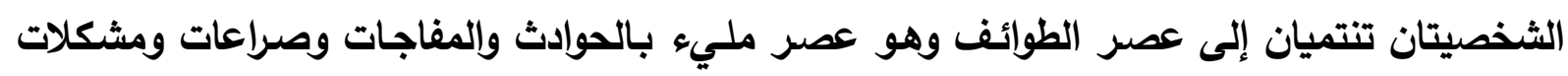
أي عصر تجاذبات سياسية واجتماعية واقتصادية وفكرية مختلفة ، وللمكانة التي يحتلها كلا الثاعرين

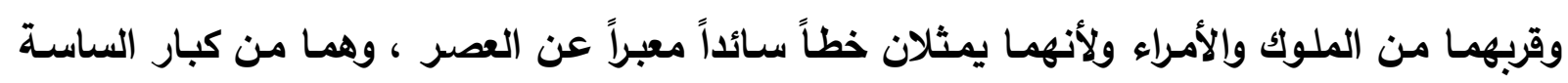

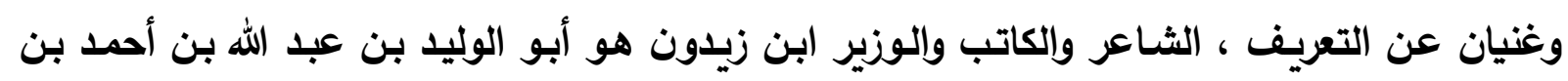

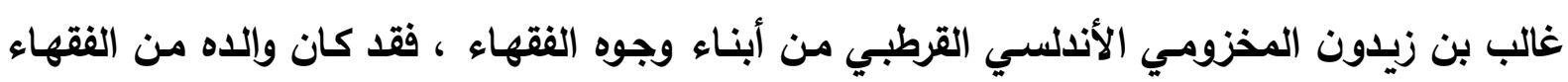

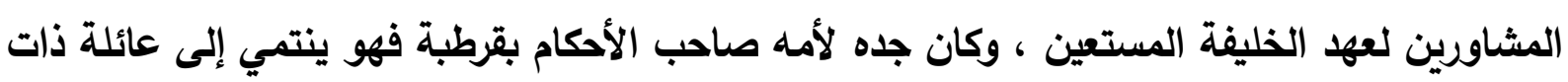

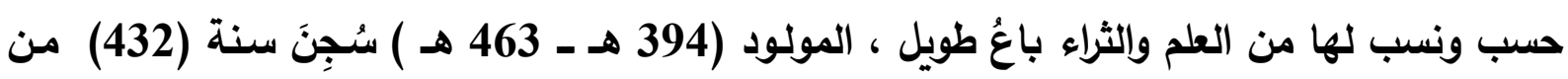

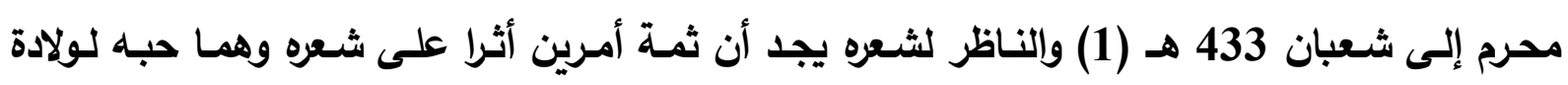

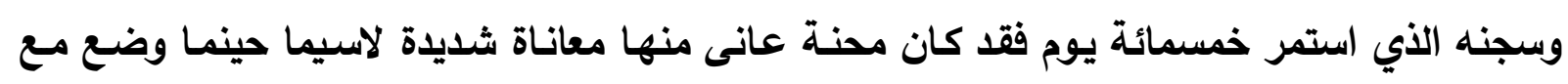

(2) اللصوص والسفلة السينة 


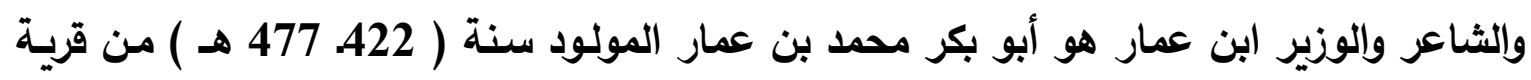

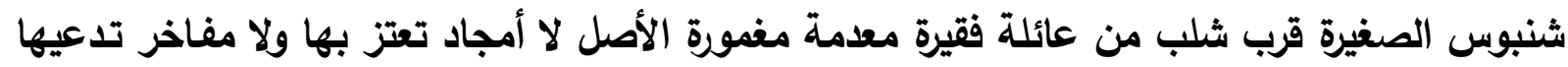

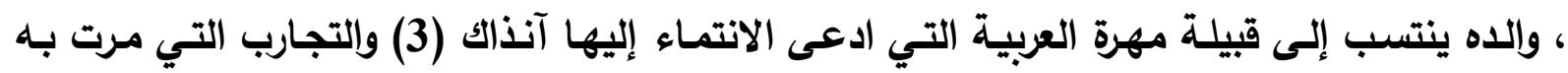
ولَّدت لايه

سوء ظن بالطبيعة الإنسانية ، فلم يعر أهمية بالرعاية والود اللذين أحاطه بهما المعتمد بن عباد ،

الثكك الذي جعله لا يثق إلا بنفسه مما قوّى بنفسه طبيعة المغامرين الوصوليين فاتجه بتفكيره ومحور

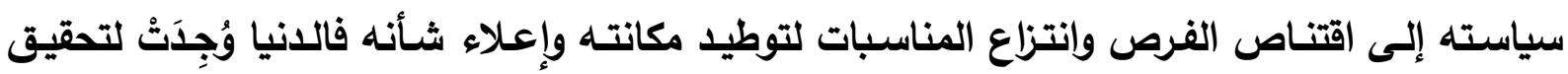

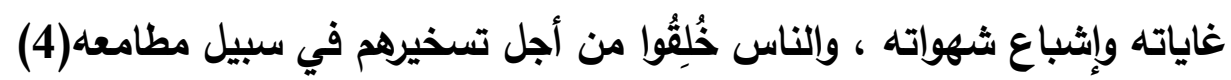

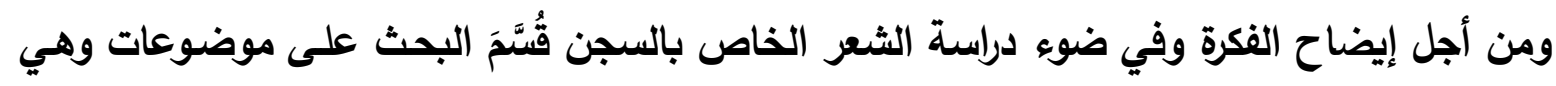

\section{شكوى ورجاء}

وهو من موضوعات شعر السجون التي نظم فيها كلا الثاعرين إذ يشكو الثـاعر فيها مصيره

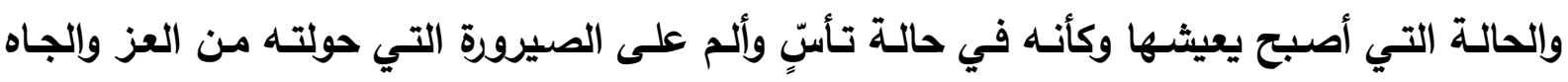

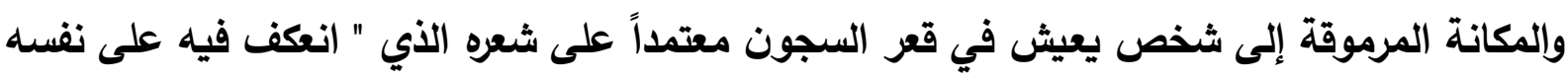

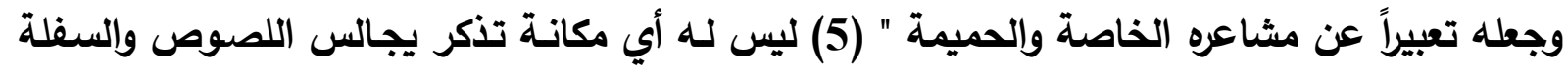

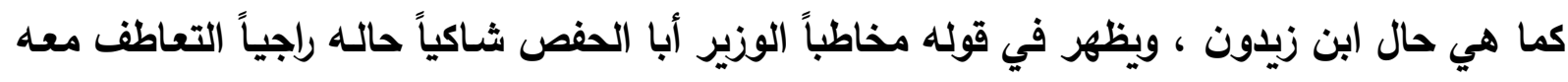

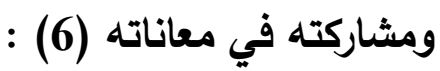

\begin{tabular}{|c|c|}
\hline يجرح الدهر وياسُو & ما على ظني بَاسُ \\
\hline ه على الآمال يَاسُ & رُبما أشرف بالمر \\
\hline ل ويرديك احتراسُ & ولقد يُنجيك إغفا \\
\hline وَالمَقَاديرُ قِيَاسُ & والمحاذيرُ سِهَامُّ؛ \\
\hline وَلَكَمُ أكدى التمـاس & ولكم أجدى قُعُودُّ؛ \\
\hline عز ناسُّ ذلَّنَاس & لدهرُ إذا ما \\
\hline 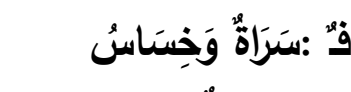 & 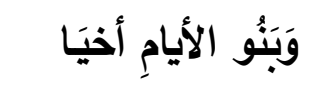 \\
\hline حَقة ذَاَكَ اللَّبَاسُ & الَّنْيًَا وَلَلَ كِنْ \\
\hline
\end{tabular}

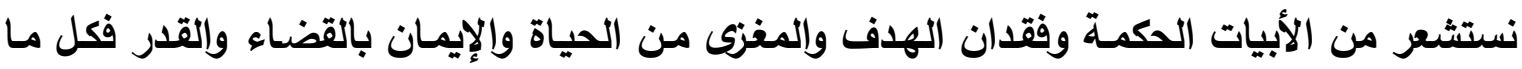
يحثث هو بمشيئة الله وقدرته ، فقد " كانت حياته نهباً للهموم والآلام ، والمحن والمصائب ، والأحداث 
والغير ، والختل وإلغدر ، والكيد والحقد ، والبغض والحسد ، والتقرب والبعد ، والرضا والنضب ، والوصل

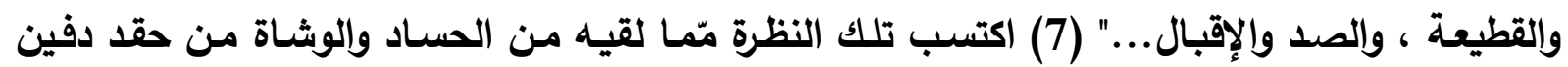

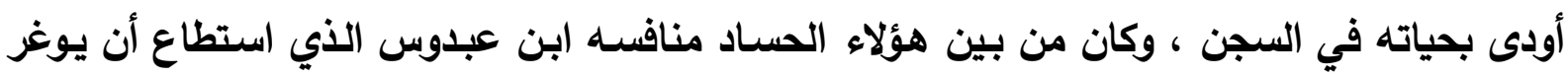

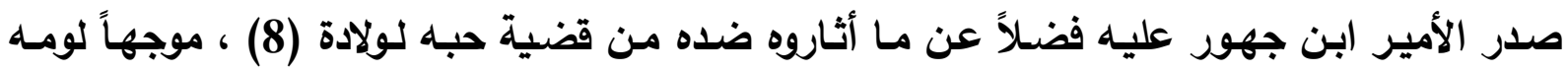

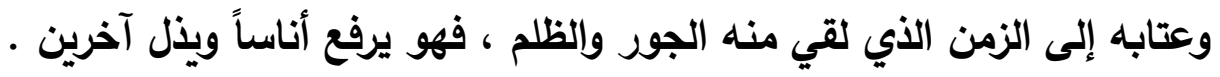

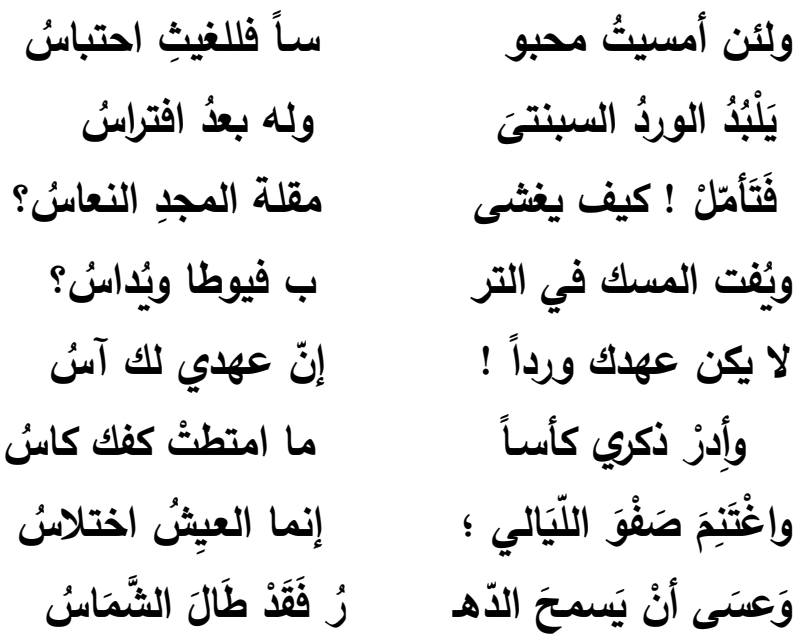

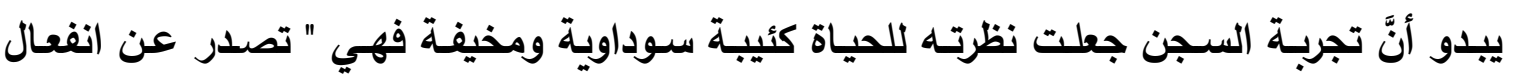

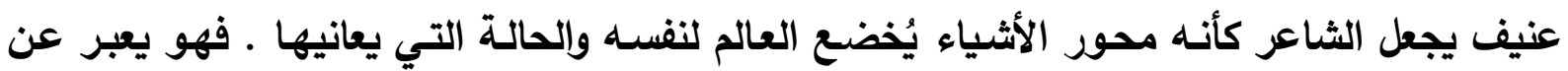

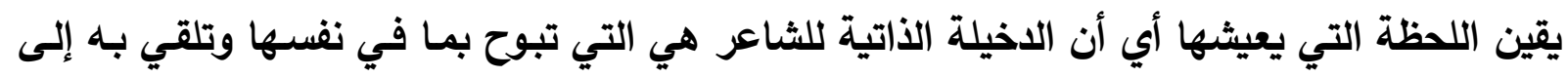
الخارج "(9) ونلحظ أيضاً استعمال الثاعر ألفاظ ( احتباس ، افتراس ، يُداس ، اختلاس ) وكلها تثعر فئه

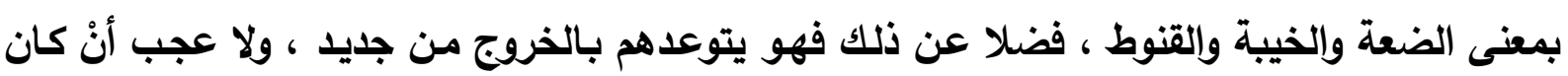

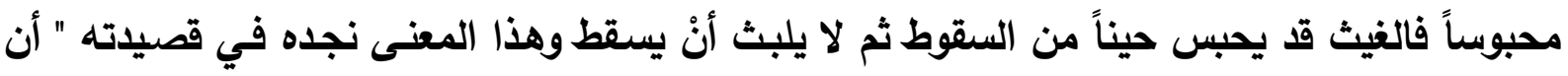

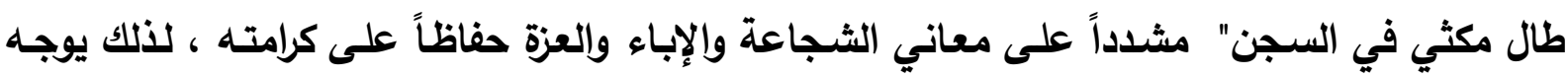

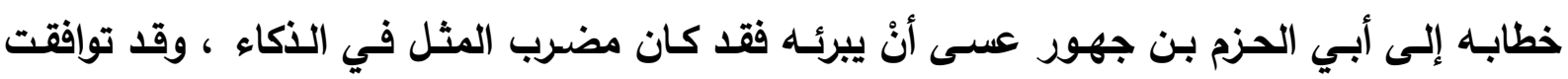

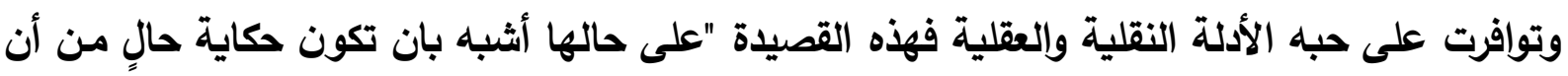

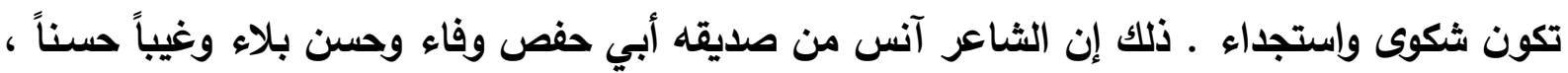

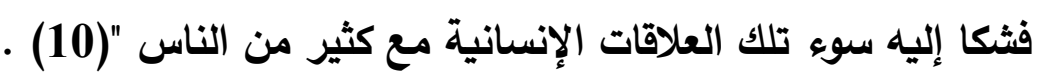

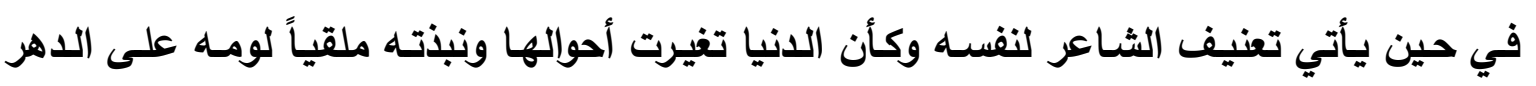

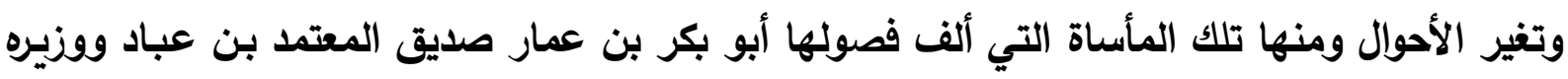

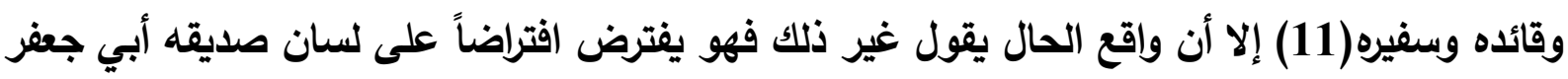

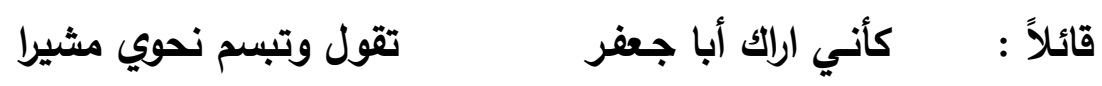
سفرت ليرجع هذا معي وزيراً فلم أر إلاً أسيرا 
وإن كان بالاهر طباً بصيرا (12) (12)

$$
\text { هو القدر الحتم يعمى الفتى }
$$

يبدو أن الثاعر قال هذه الأبيات مخاطباً الوزير مشيراً إلى ذلة الحال والههوان الذي أصابه ، فيعيب

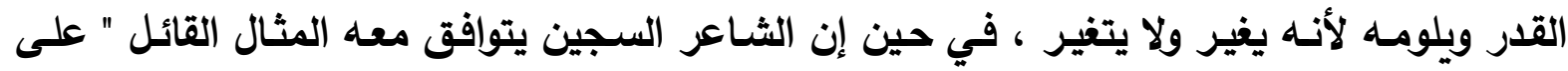

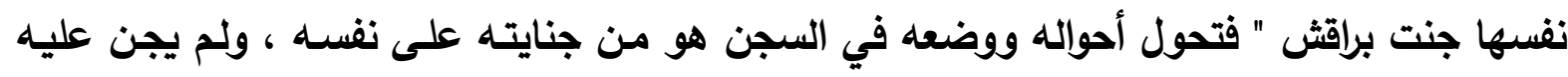
الناس ولا حتى صديقه بل طموحه غير المشروع وخيانته .

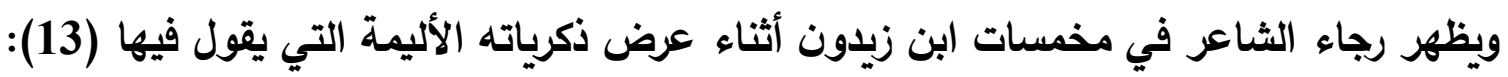

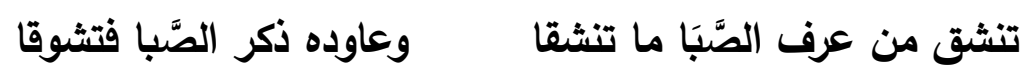

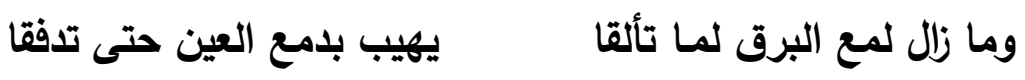

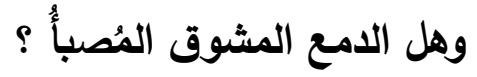

خليلي إنْ أجزع فقد وضح العذرُ وإن أستطع صبراً فمن شيمتي الصبرُ

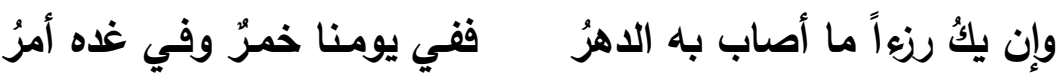

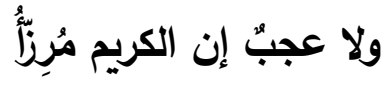

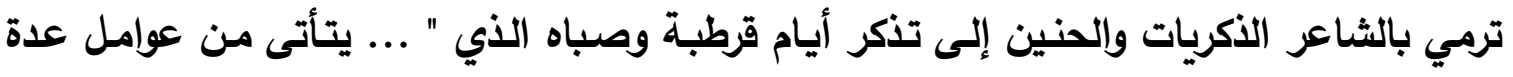

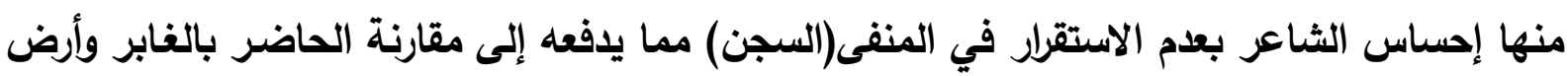

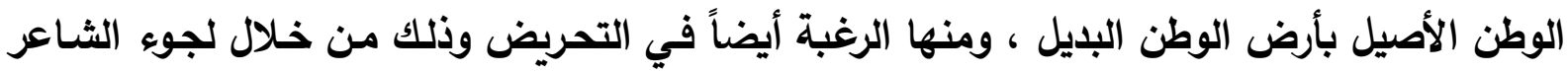

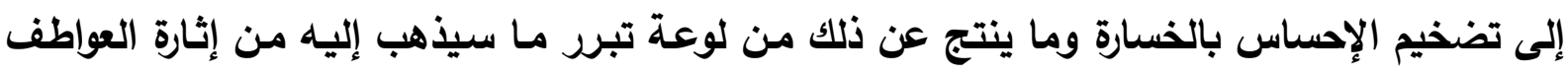

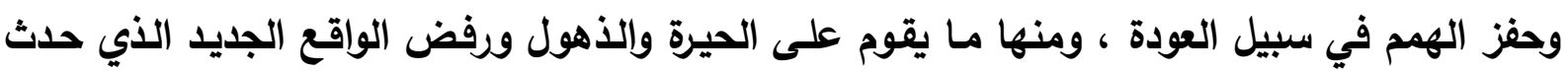

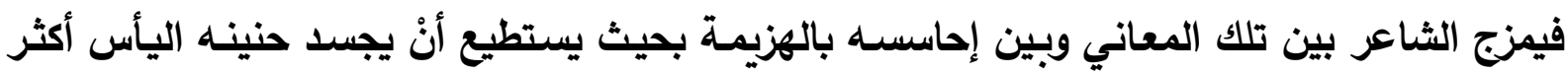

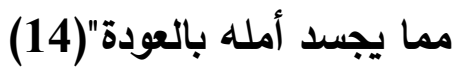
فتبدو دموعه بالانهيال ولمن يتوّجه بدعائه ؟ يتوجه بدعائه إلى أصدقائه ليوضح لهم خوفه وجزعه من

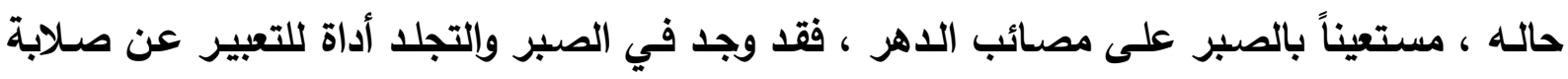

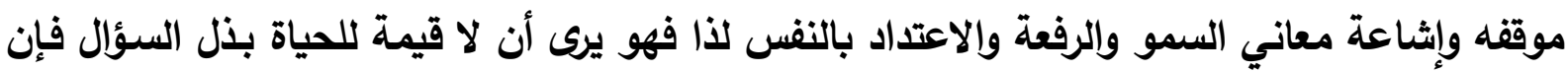

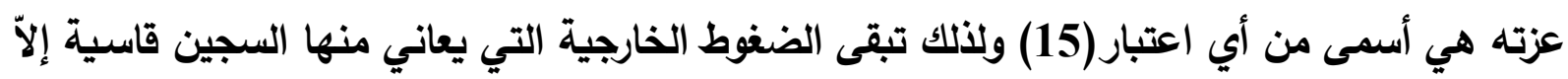

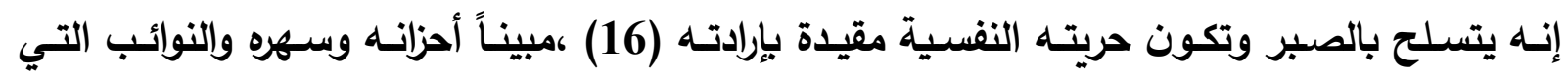

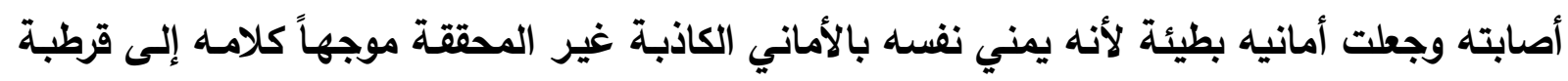

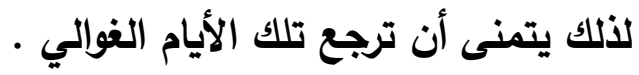


ولأن " السجين أول عهده بالسجن يبرح به الألم ،وينهش قلبه الحزن وتعصف بصوابه الوحثة ولولا

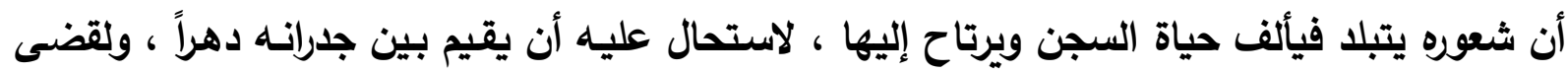

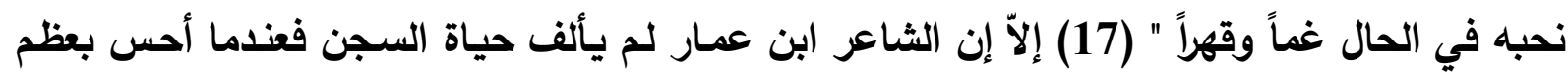
جنايته استغاث بأخيه أبي الفضل حسداي صاحب شقورة طالباً عفوه وصفحه عنه ، وقد نظم أبياتاً واصفاً موضع اعتقاله : كالطل يوقظ نائم الزهر أدرك أخاك ولو بقافية في غير موماة ولا بحر فلقد تقاذفت الركاب به

جعلته مرقاة إلى النسر عال كان الجن إذ مردت حتى استربت بصفحة البدر وحش تناكرت الوجوه به نسرين من فلك ومن وكر قصر تمهـ بين خافقتي

وأطعت أمر مضيع أمري ووصلت خدمة قاطع سببي

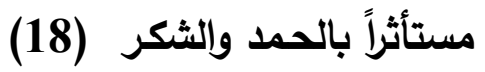
دع ذا وصلنا غير مؤتمر

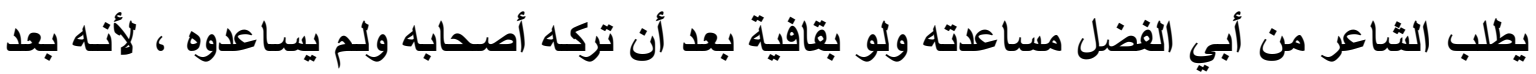

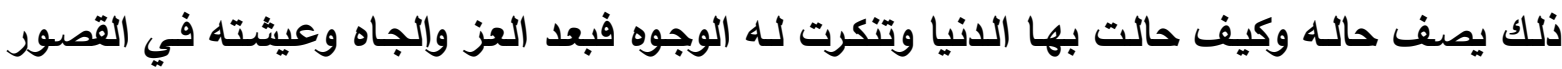

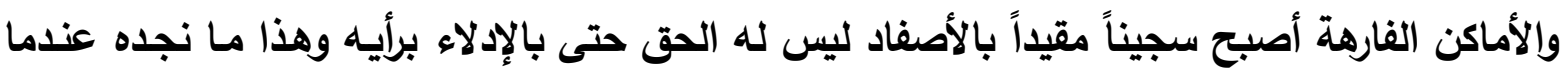

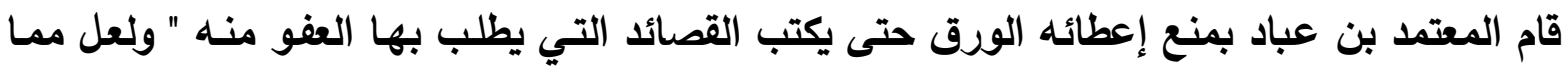

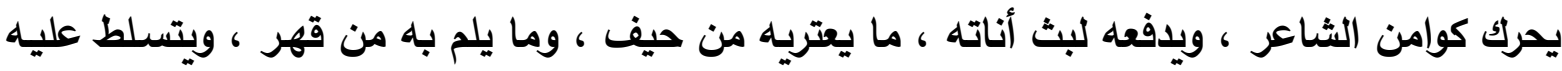

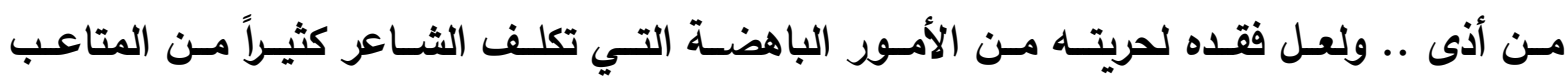

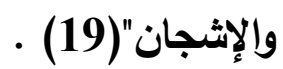
ويشكو الثاعر ابن زيدون حاله مستدركاً شكواه ومعرضاً بالحاقدين وإلحاسدين بقوله :

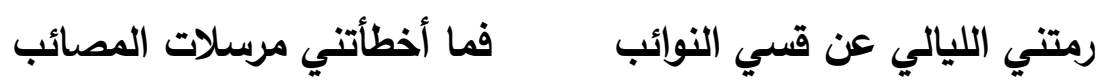

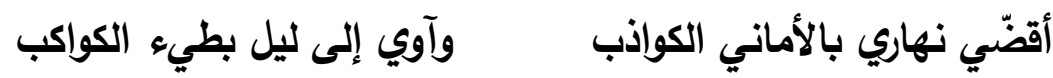
وأبطا سار كوكب بات يُكلأ

$*$ ولا يغبط الأعداء كوني في السجن ؛ فإني رأيتُ الثمس تحصنُ بالاجن

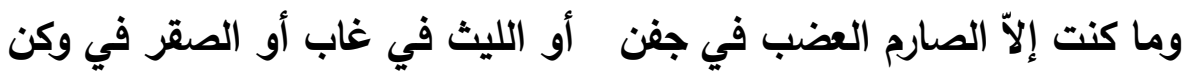
أو العلق يخفى في الصوار ويُخباًُ 
إنَّ استعمال الثـاعر عبارتي ( رمتني ، ما أخطأت ) جاء للإيحاء بتسديد الرمية وشدة وقعها

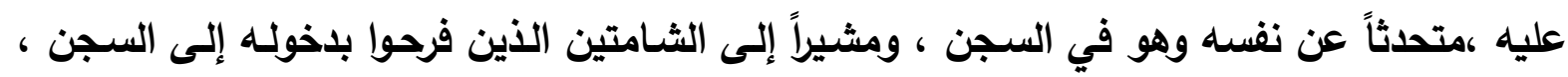

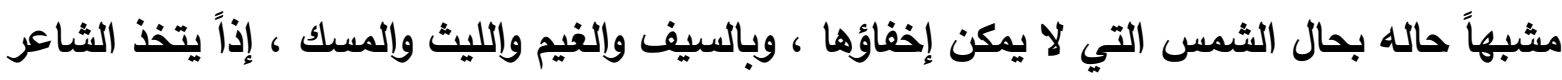

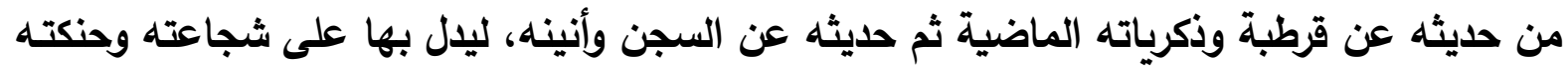

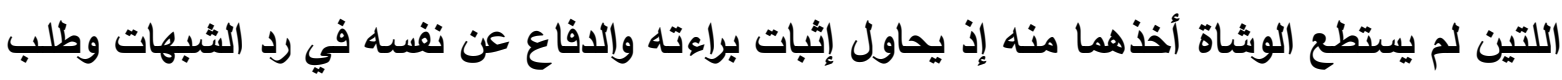
النصرة له .

ويستعين ابن عمار بصاحب المرية في مدة اعتقالهه في شقورة ويخبره بحاله قائلاً :

رأسي بأنواع من المال

أخدمسه مدة إمهالي

من ضمني بالثمن الغالي

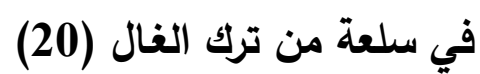

أصبحت في السوق ينادي على

فهل فتى يبتاعني ماجد

تاله لاجار على نقده

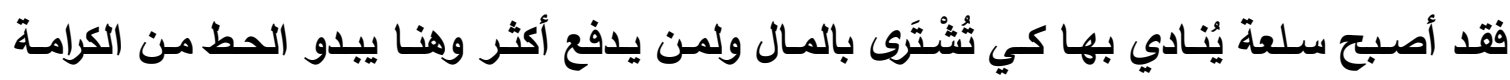

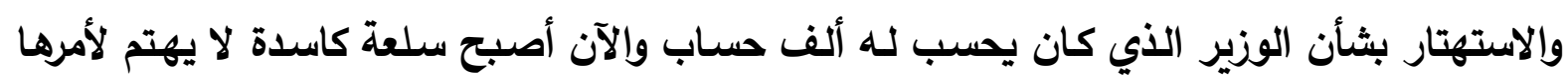

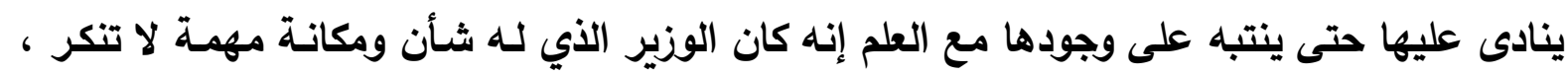

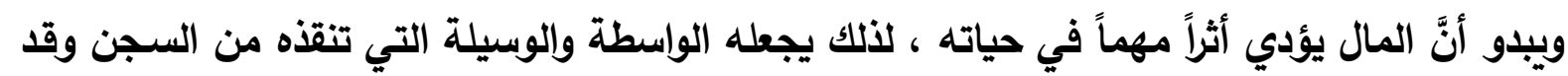

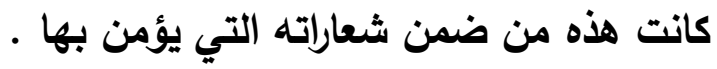

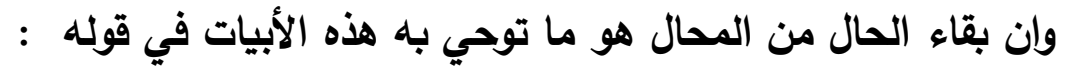

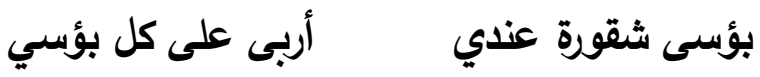

فظلت أطلب موسى (21)

$$
\text { فقدت هرون فيها }
$$

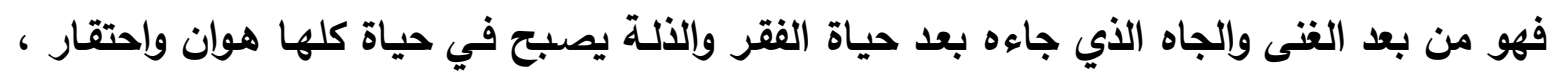

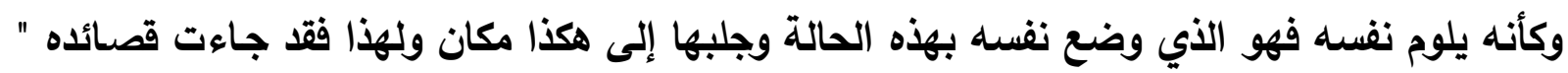

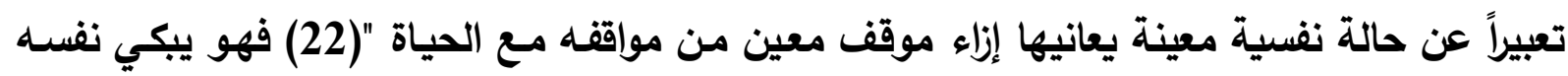

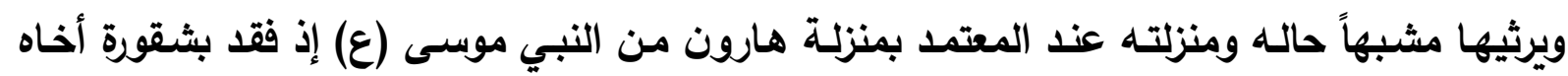
المعتمد وصحبته عندما أُلقي في السجن عندئه عند المعتد

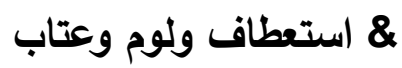

وفيه يتوجه الثاعر مستعطفاً إلى كسب ود الأمير والفوز برضاه وصفحه مستعملاً الوسائل والسبل وعاب كافة 
لتحقيق مأربه والحصول على أهدافه فهو " وسيلة لاستدرار عطف آسريهم ، واستمالة قلوب الحكام

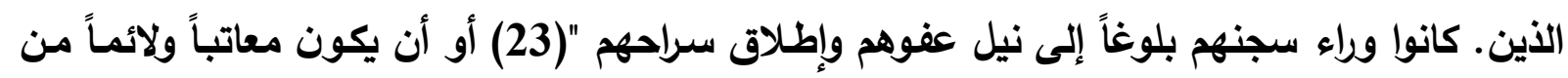

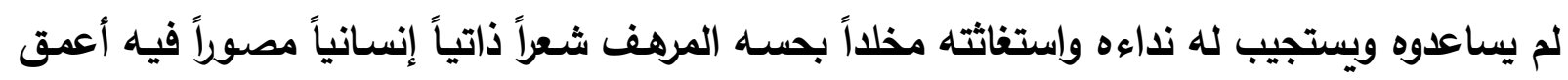

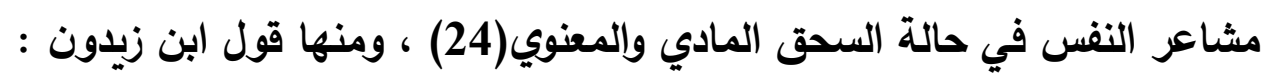

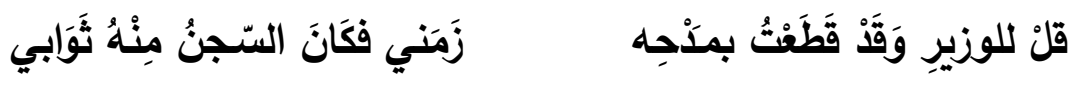

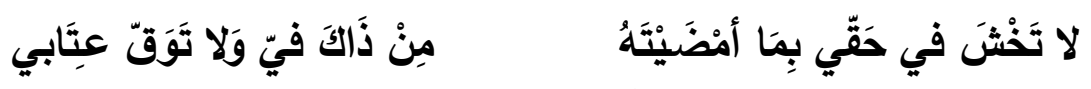

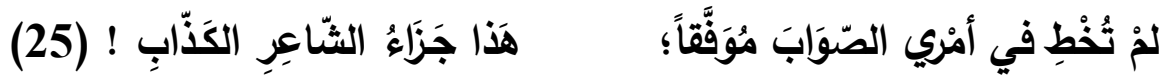

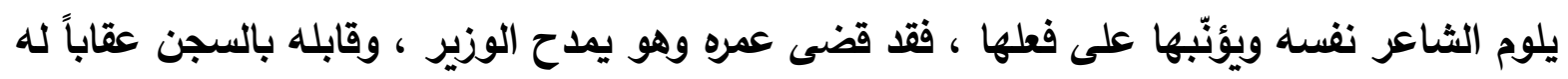

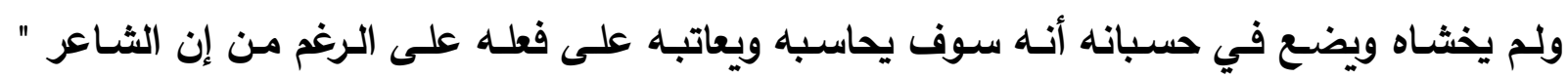

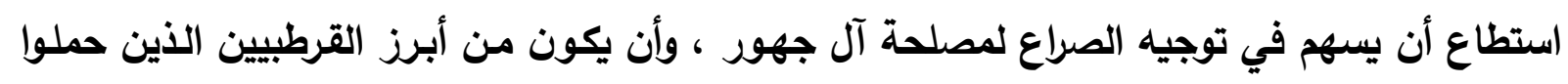

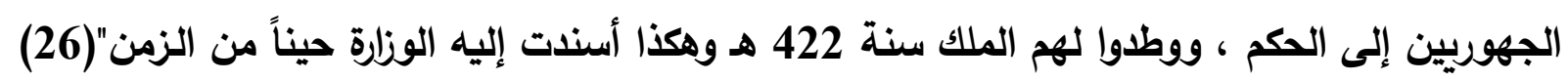

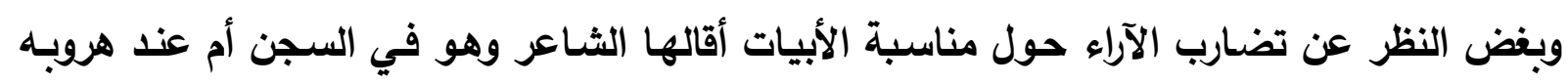

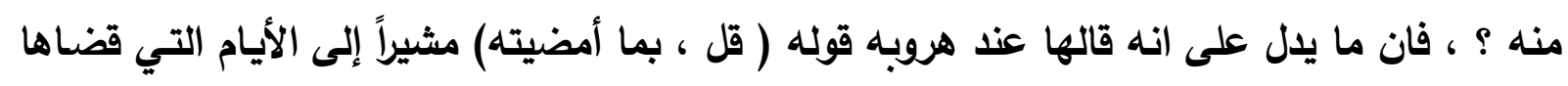

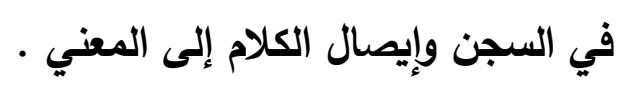

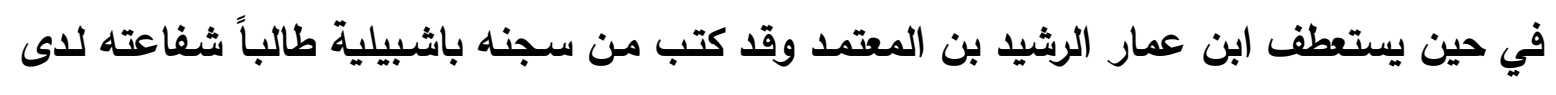
قاصداً بالسلام قصر الرشيد
قل لبرق الغمام ظاهر بريدي وتناثر في صحنه كالفريد$$
\text { ضجتي في سلاسلي وقيودي }
$$
قلت : إني رسول بعض في سلعبيد وفيوني (27) فتقلب في جوه كفؤادي وانتحب في صلاصل الرعد تحكي

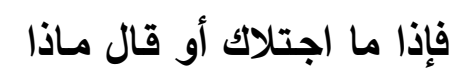

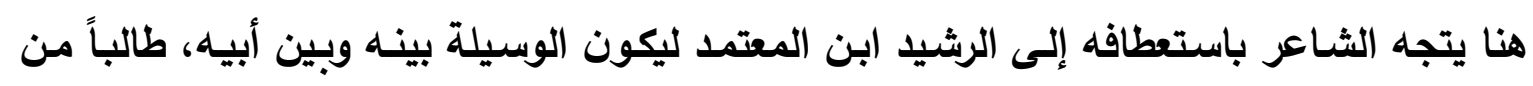

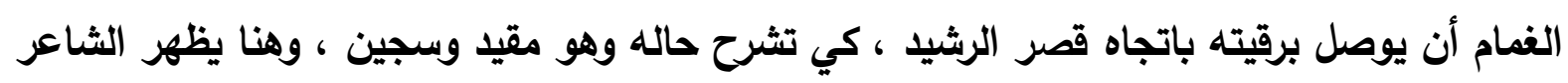

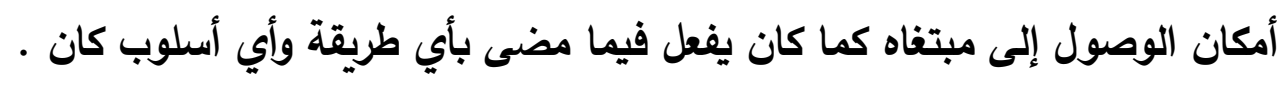

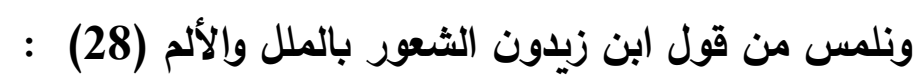

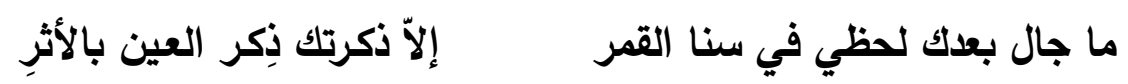

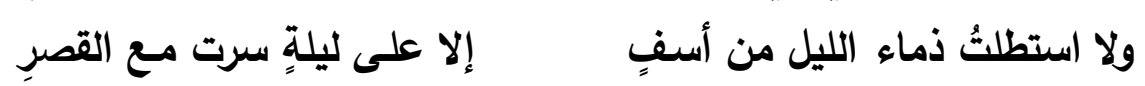

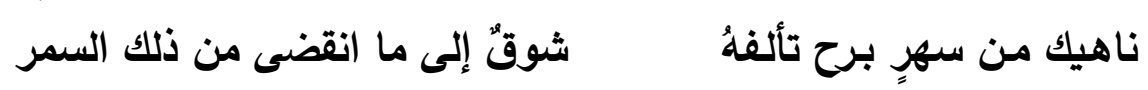

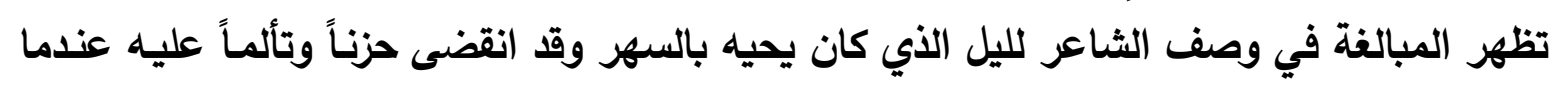
اقتيد إلى السجن و " لا شك في أن شقاء الإنسان في هذا العالم المضطري يعود إلى إدراكه أن ذاته 
سجينة حبيسة وأن طاقاته الحيوية تتبدد عبثاً إذا هو لم يستطع أن يبلورها في إطار فكرة واقعية نابعة

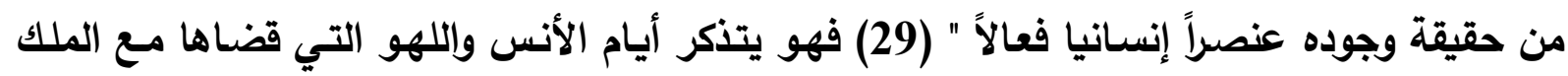

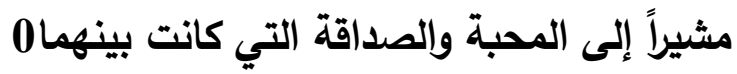
وكتب ابن عمار إلى الراضي بن المعتمد مستعطفاً ومستثفعاً لايه بقوله :

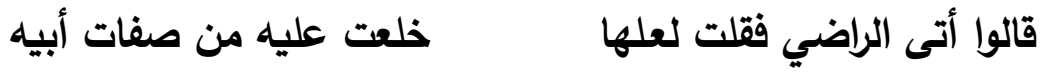

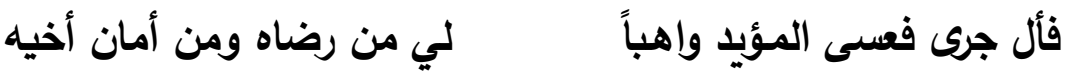

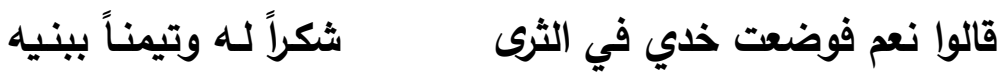

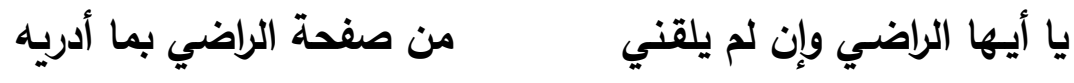

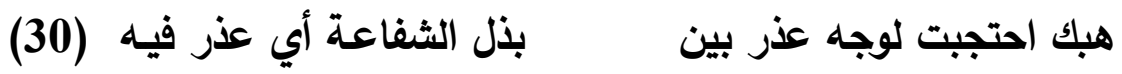

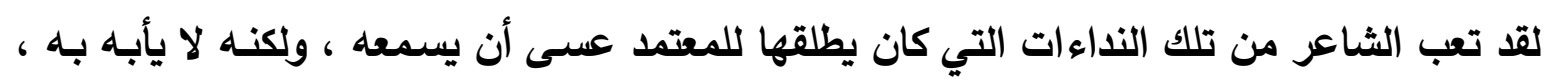

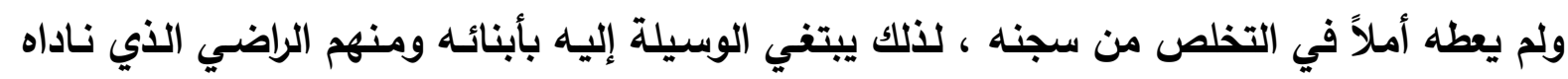

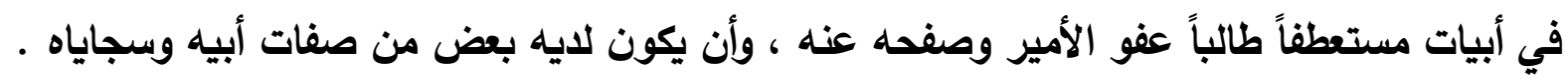
ولعل أكثر ما كان يقضّ مضجع ابن زيدون هو عمل الحاسدين الذين أطاحوا به قوله :

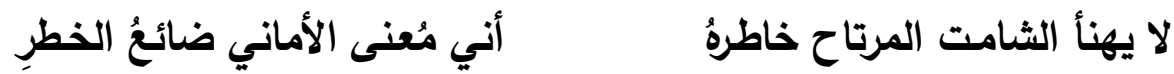

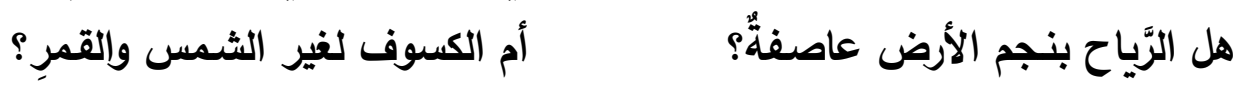

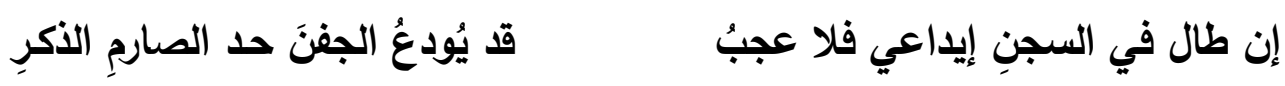

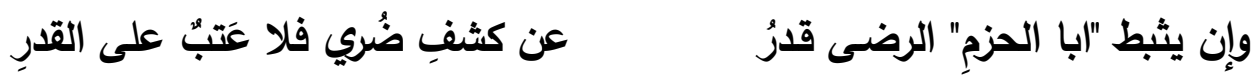

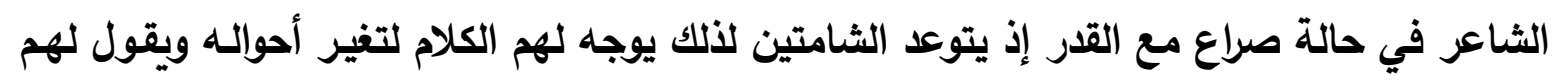

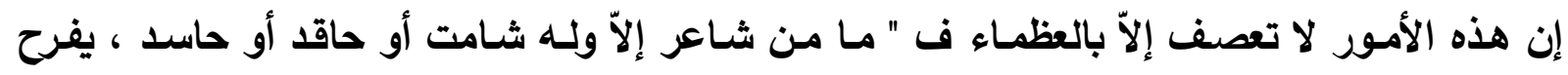

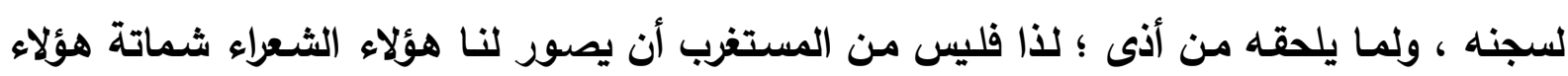

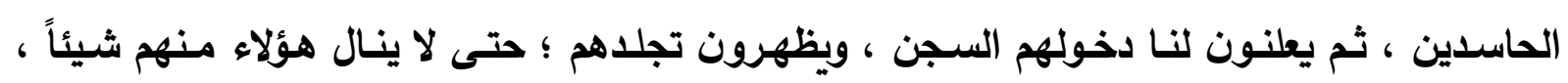

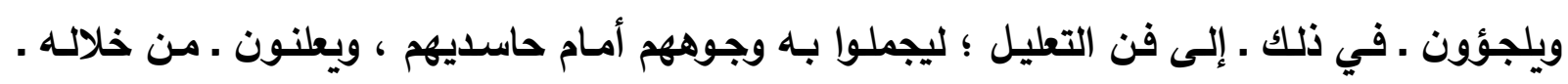

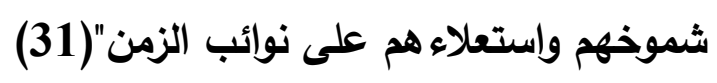
وأن وجوده في السجن لا يعني نهايته ، وإن تأخر أبو الحزم بن جهور عن عن إنهائ إنقاذه من محنته عاتباً

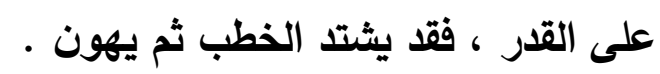

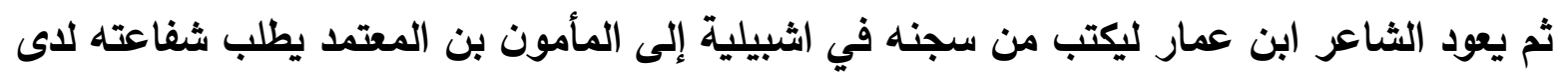

$$
\begin{aligned}
& \text { أو قلت مافي نفسه يكفيني } \\
& \text { يسرى النسيم بها على دارين } \\
& \text { هلا سألت شفاعة المأمون } \\
& \text { ما ضر لو نبهته بتحية } \\
& \text { يوم الجلاد الحين بعد الحين } \\
& \text { وهززت منه فقد يقلب سيفه }
\end{aligned}
$$




$$
\begin{aligned}
& \text { لو أن أمري في يد المأمون } \\
& \text { وكفاء من فوق كفاه ودون } \\
& \text { بيدي من المأمون أوثق عصمة } \\
& \text { أمري إلى مولى إليه أمره }
\end{aligned}
$$

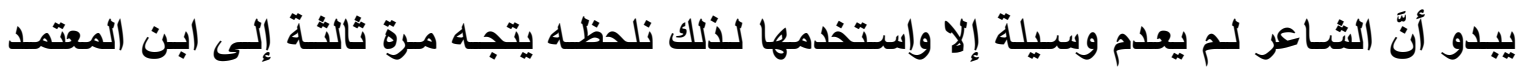

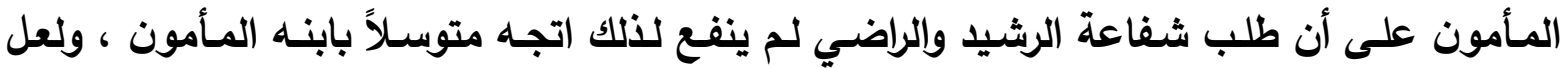

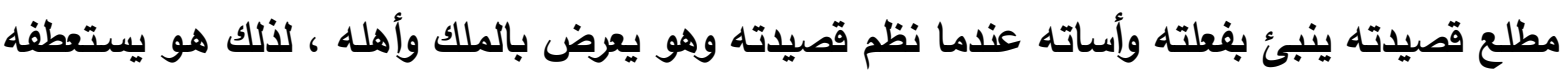

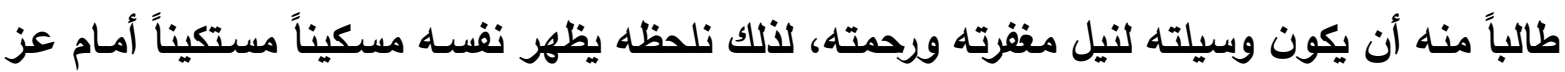
الملك وسطوته :

حيث استوى الخصمان حقاً وإلتقى عز الغني بذلة المسكين

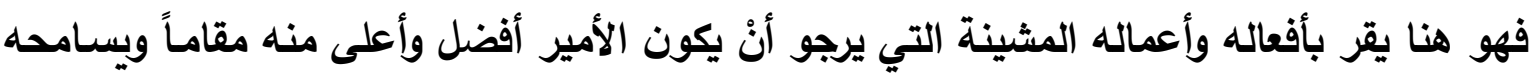

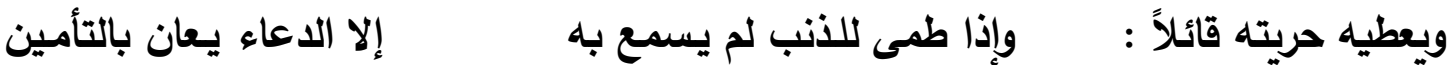

$$
\begin{aligned}
& \text { كم أسكب العذب الفرات على فمي يرمي يدي باللؤلئو المكنون }
\end{aligned}
$$

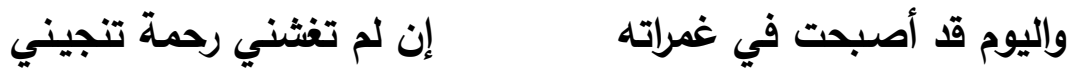

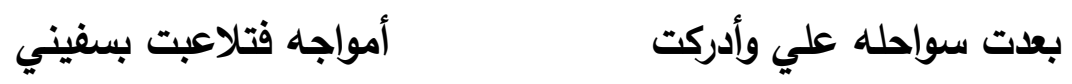

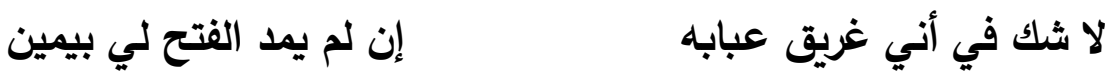

كأن الثاعر يطلب من ابن الأمير المعتمد (الفتح) أن يستخدم جميع وسائله من أجل إقناع ابيه ،

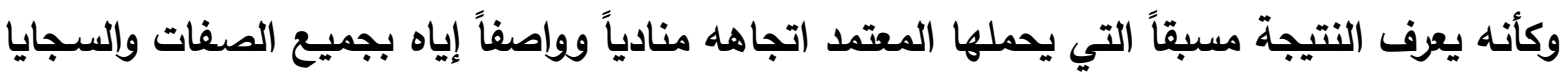
التي تدل على الثجاعة وإلفروسية قائلاً في ذلك :

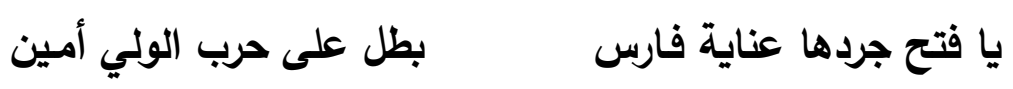

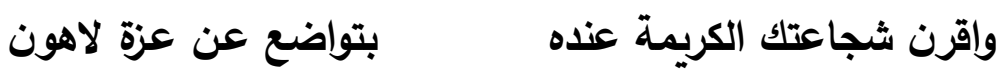

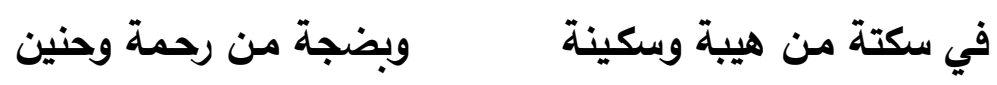

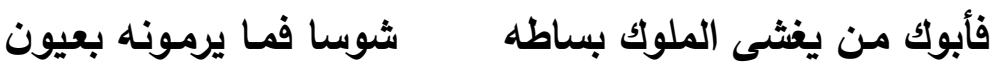

ويلقي ابن زيدون اللوم والعتاب على الوشاة قائلا :

$$
\begin{aligned}
& \text { ما للانوب التي جاني كبائرها } \\
& \text { مَنْ لم أزل من تأتيه على ثِقَةٍةٍ }
\end{aligned}
$$

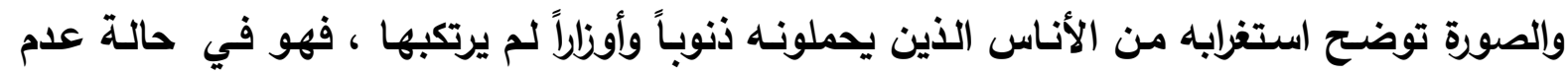

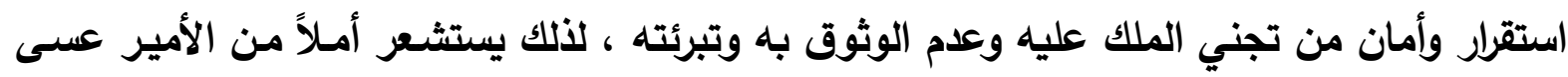

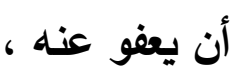
فالثاعر المجيد هو من يستطيع أن يحول صوره إلى وسيلة لقراءة ليس أفكاره فقط وإنما انفعالهه

$$
\text { (33) العميق أيضاع المجياً }
$$


وعلى الرغم من معرفة الثاعر ابن عمار للمعتمد بحكم الصداقة والملازمـة لـه ، فإنه لـ يتق ولم

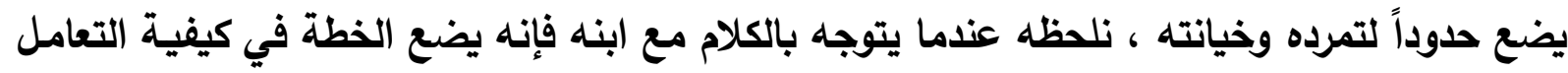

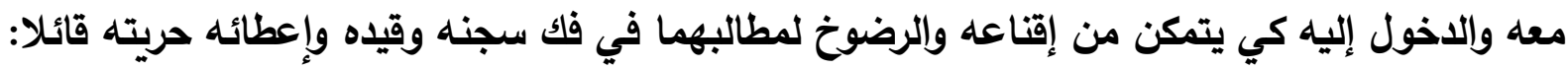

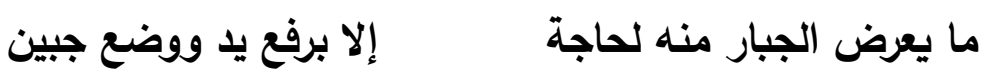

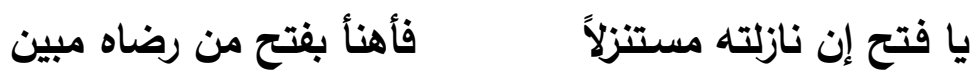

$$
\begin{aligned}
& \text { وليخلصن إليك من أعلاقه علق يثد عليك كف ظنين }
\end{aligned}
$$

\& \& اعتذار ووصف حال

وهي من الموضوعات الثعرية التي تناولها الثعراء وهم في السجون يعتذرون راجين من سـاجِيهِه

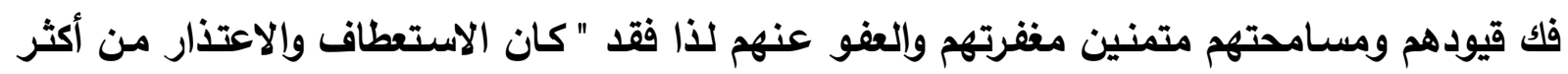

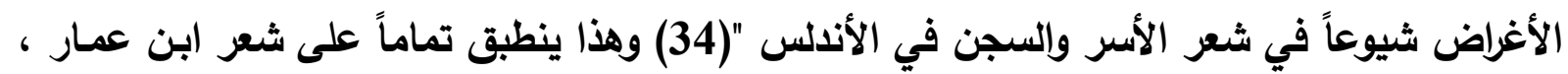
و نجد الاستعطاف عند ابن زيدون ولكن بدون ذلة محافظاً على كرامته وهيبته ، في حين لـ لم نجداه

يقول الثاعر ابن زيدون واصفاً مرارة الاعتقال (35) وتثاركه الطبيعة آهاته " إذ اكتسبت مشاعرهم

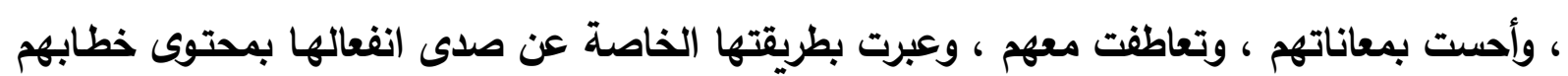

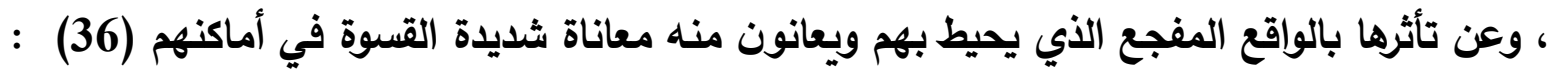

ويطلب ثأري البرق مُنصلت النصلِ فئاء

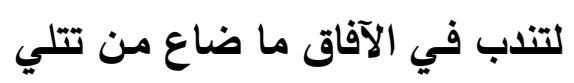

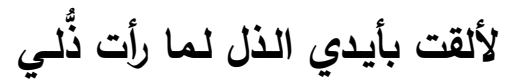

بمطلعها ما فرق الدهر من شملي لالاي

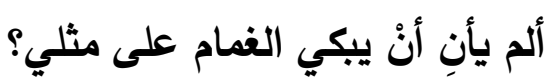

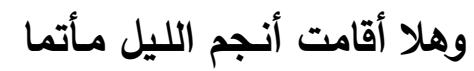
ولو أنصفتني وهي أشكال همتي ولا افترقت سبعُ الثريا وغاضها

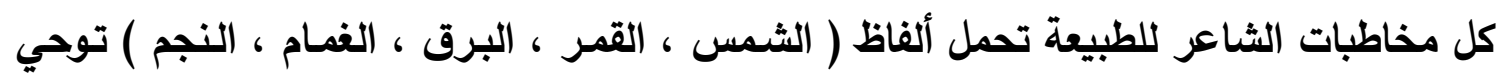

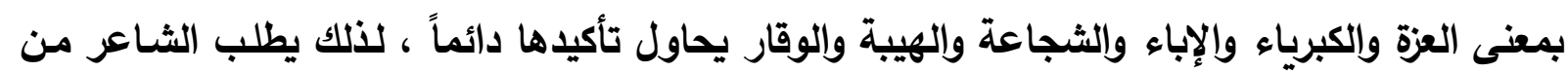

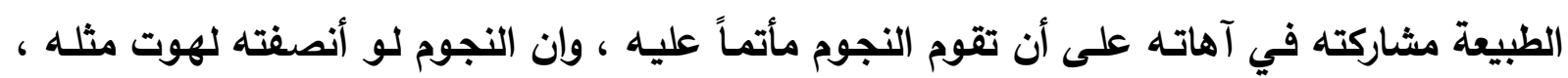
وانتفضت حزناً على ما فعله الدهر من تثتيت شمله ، فهو يشعر بالطبيعة شعوراً عميقاً ويرفعها إلى مانى

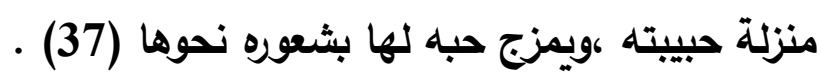

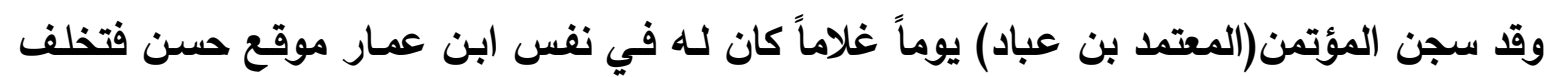

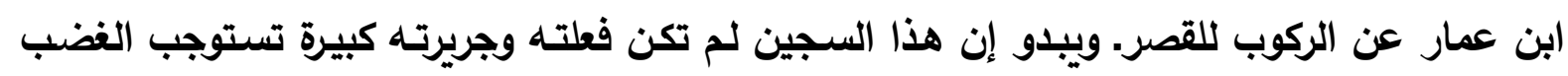

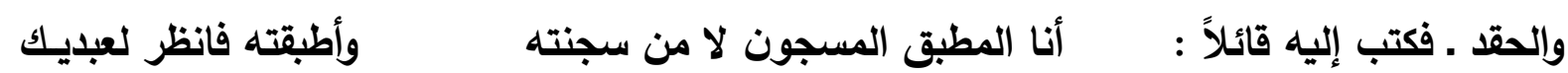
أو دع

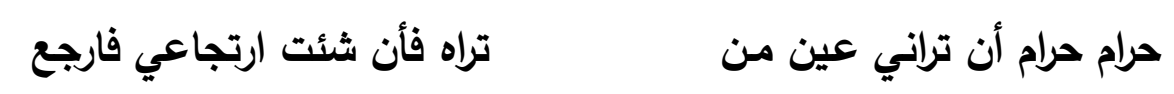




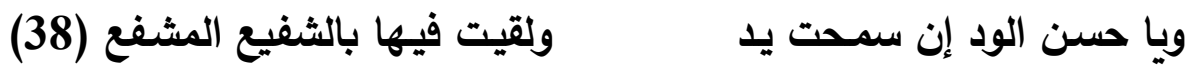

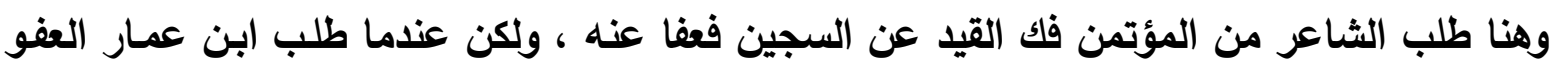

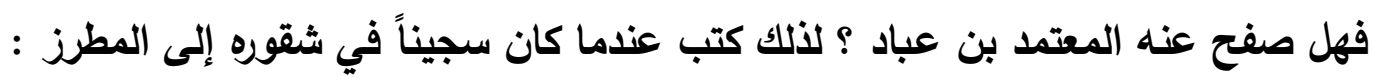
تراءى بعيني إن أردت مبرتي وسبب إلى الحسنى ولو بقسيم

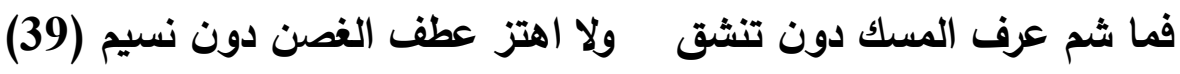

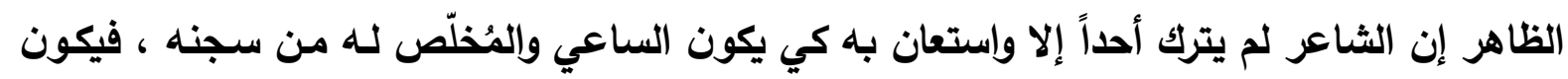

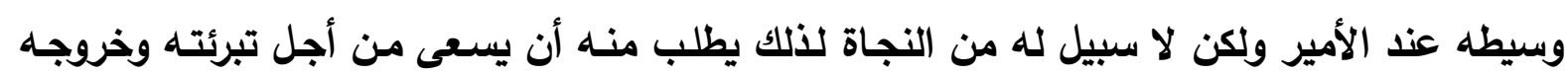

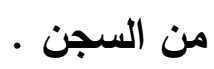

وتقود مشاعر الحزن ابن زيدون وهو في السجن إلى تذكر والدته ولأن " الصورة لا يشترط في

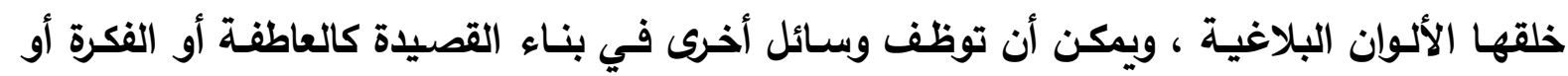

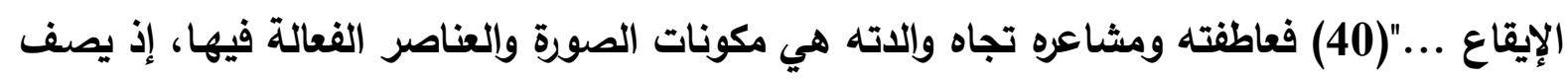

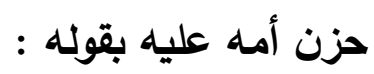

طوت بالأسىى كشحاً على مضضِ الثكلِ

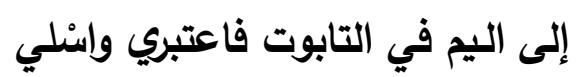

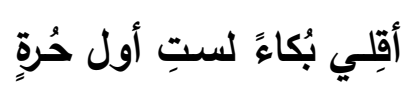

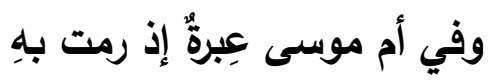

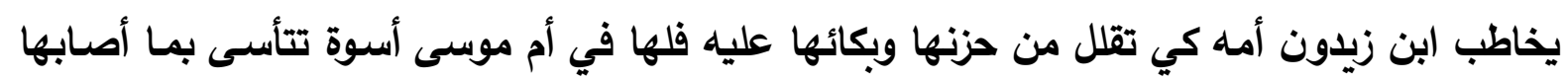

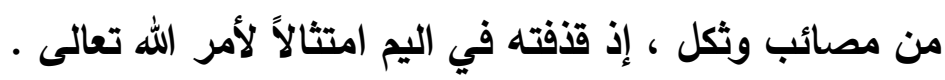

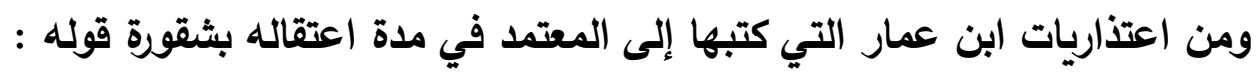

$$
\begin{aligned}
& \text { نفسي تحن إلى فداء }
\end{aligned}
$$

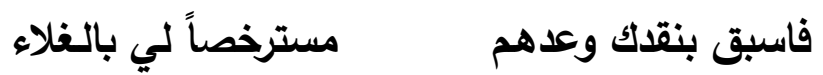

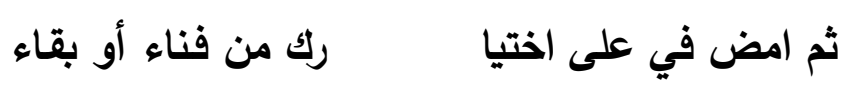

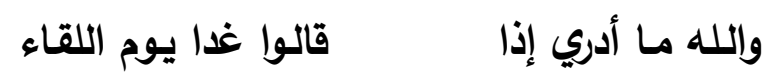

$$
\begin{aligned}
& \text { مـا أقتل الحالين لي إن كان خوفي اوحيائي (41) }
\end{aligned}
$$

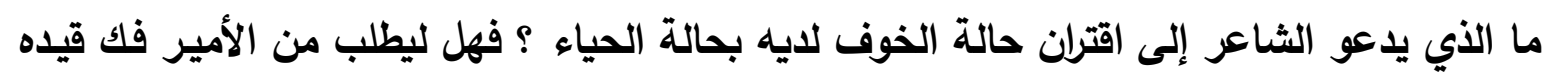

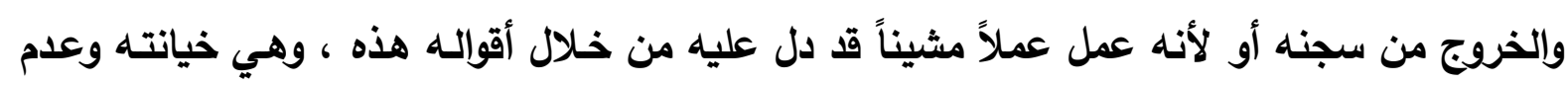

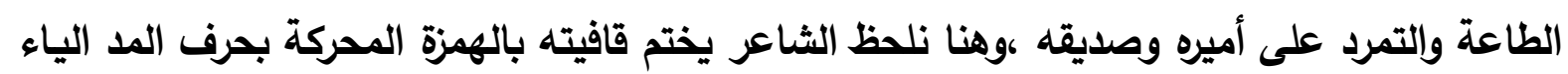

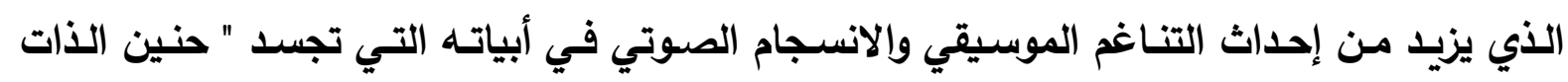

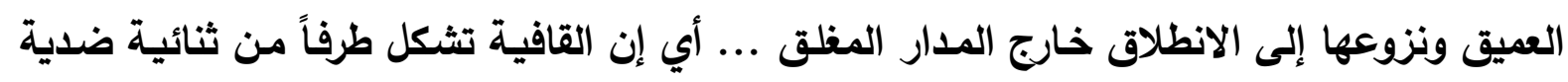

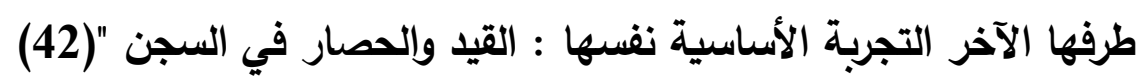


وتعود مشاعر الأسى لدى الثـاعر ابن زيدون ثانية ويسترجع أياماً خوالياً قضاها في قرطبة مـع

وشط بمن نهوى المزارُ وما شطوا

حوادثُ لا عقد عليها ولا شرط

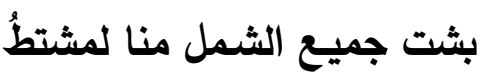

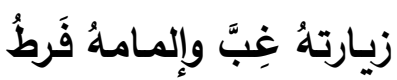

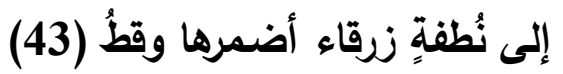
قائلاً :

حبييته شحطنا وما للدار نائي ولا شحطُ

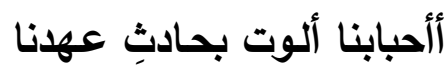

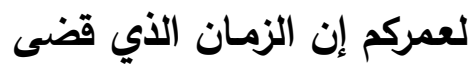

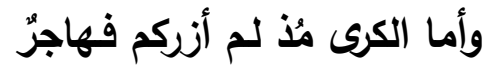
وما شوق مقتول الجوانح بالصدى

تقود الثـاعر الذكريات والأثشواق إلى الأمـاكن التي يحبها فهي معهد صبه صباه وحبه الذي اضطره السجن إلى

الابتعاد عنها لذلك ذهب إلى هذا المكان أولاً عندما هرب من السجن لكثرة حنينه إليه إذ تبدو "

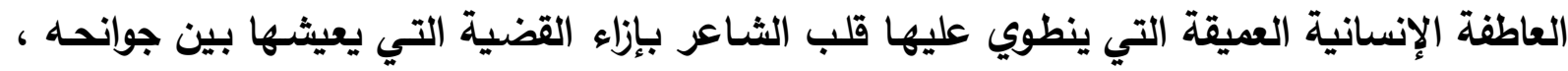

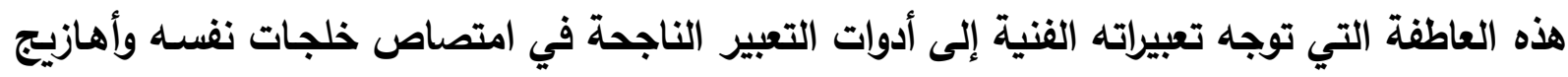

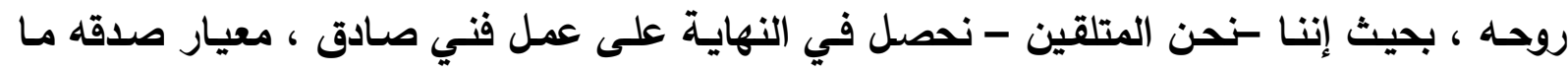

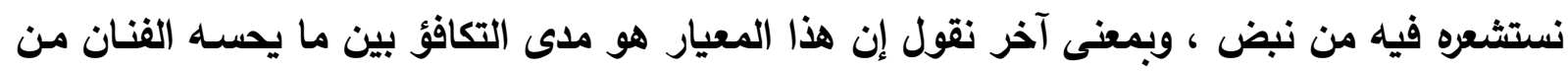

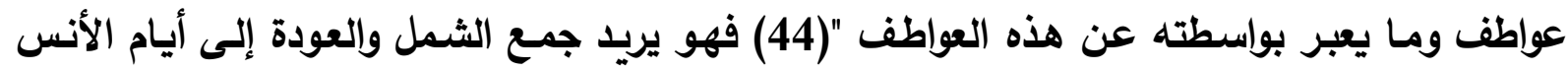

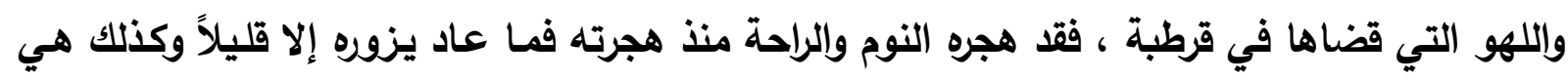
أشواقه .

ويمدح ابن عمار المعتمد بصفات الكرم والجود متناسياً إن كثرة كرمسه وسماحته كانتا من الأسباب

التي دعت إلى التمادي بتصرفه معه والتمرد عليه قائلاً فيها (45) :

د ويا روضـة الندى والجود

ولسساني رطب على التغريد
كنت أشدو عليك يا دوحة المج

إذ جناحي ند بظلك طلق

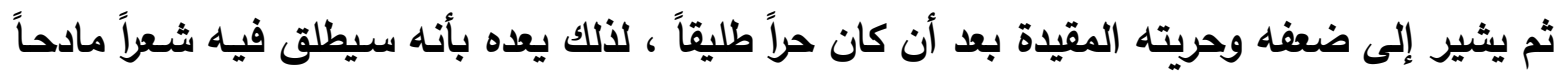

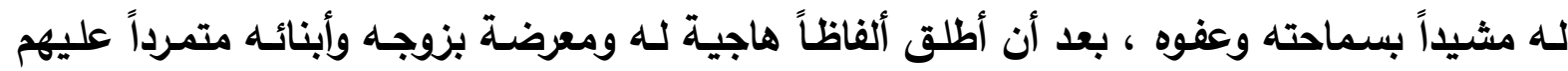

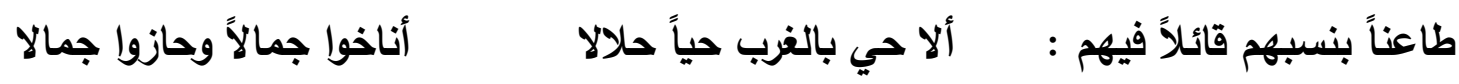

$$
\begin{aligned}
& \text { وقدما عهدتك تهوى الرجالا } \\
& \text { أراكك تورى بحب النساء }
\end{aligned}
$$

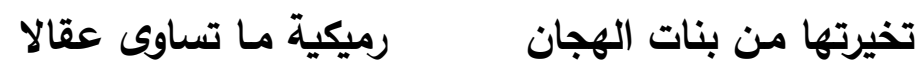

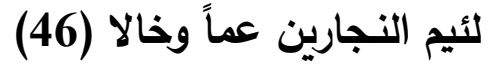

$$
\begin{aligned}
& \text { فجاءت بكل قصير العذار } \\
& \text { مؤكداً موقفه في السجن بقوئه : }
\end{aligned}
$$




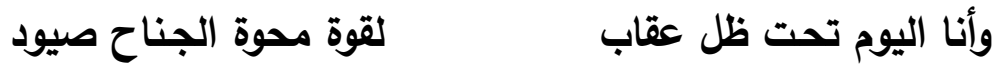

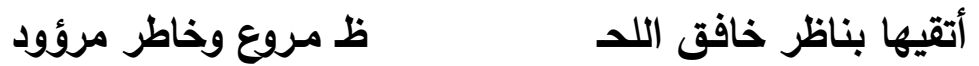

$$
\begin{aligned}
& \text { غير أني سأصطفي لك جهاي }
\end{aligned}
$$

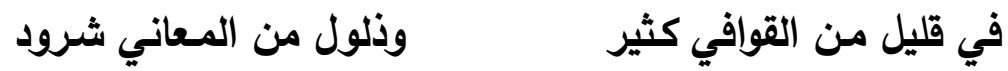

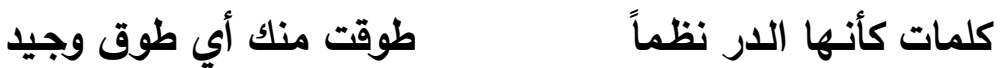

ويختم السجين أبيات اعتذاره طالباً منه ولو نظرة تكون لله رحمة تجلو حزنه وتكون المعين له بقونيه

$$
\text { مشفق يستجيب لي من قريب }
$$

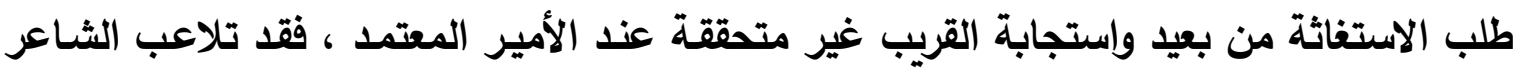

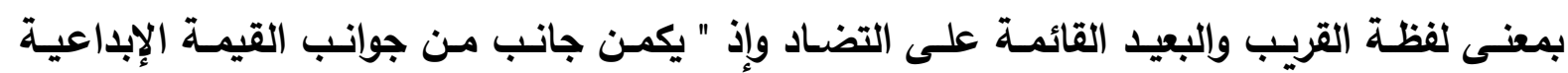

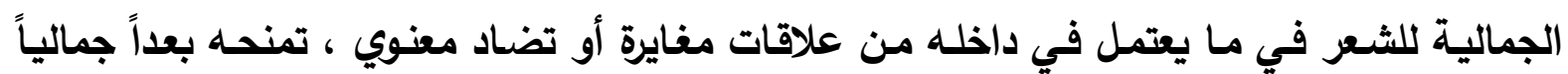

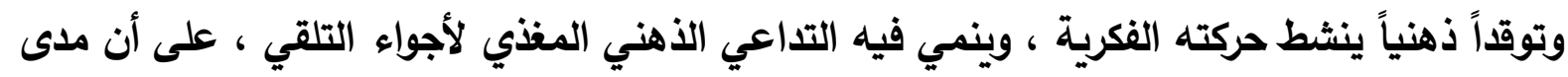

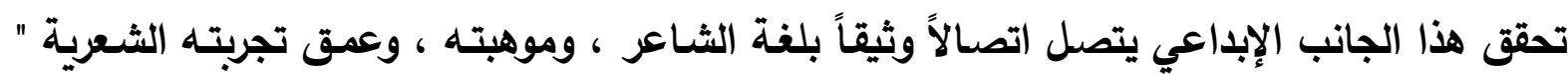

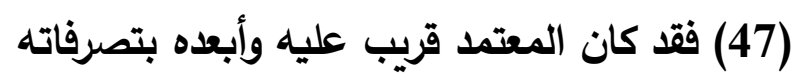

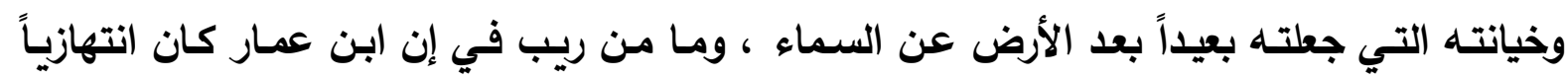
وصولياً لا يهتم بصداقة ولا عهاً (48). وفي قول ابن زيدون :

لمستحكُ الأسباب مستحصدُ الحبل ترى الفرع إلا مستمداً من الأصلِ

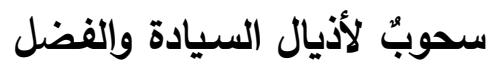

وإن رجائي في الهمام ابن جهورٍ همامٌ عريق في الكرام وقلما

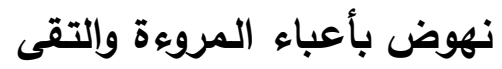

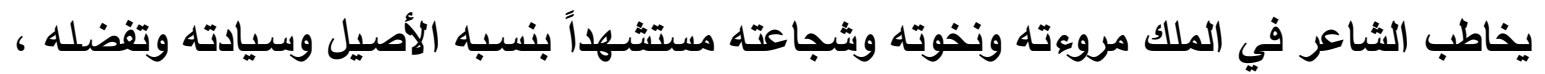

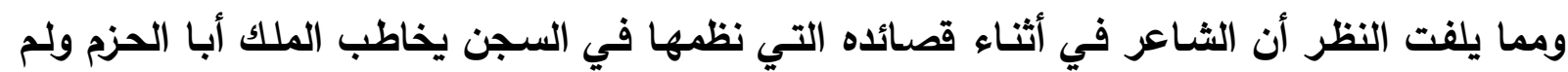

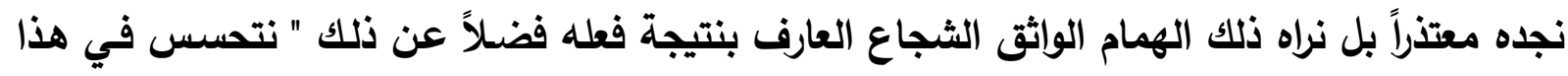

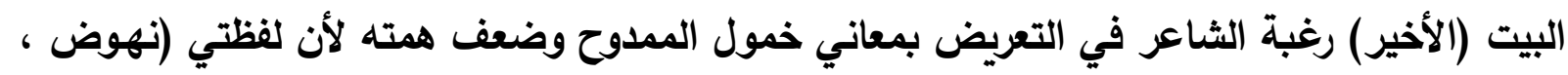

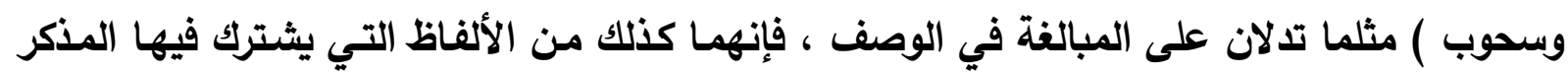

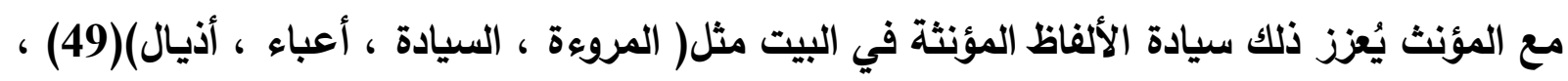

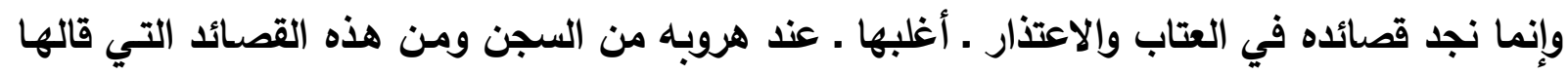
معاتباً أبا الحزم بن جهور : مئل 
عُتباك- بعد العتب- أمنيةٌ مالي على الدهر سواها امتزاج!(50)

ثم يكمل قصيدته اللامية بعد مناجاة الملك ونعته بسجايا الثجاعة وصفات الكرم قائلاً :

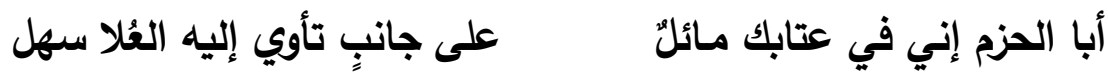

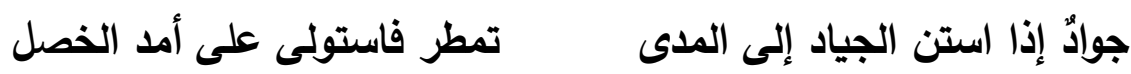

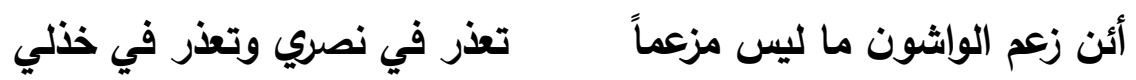

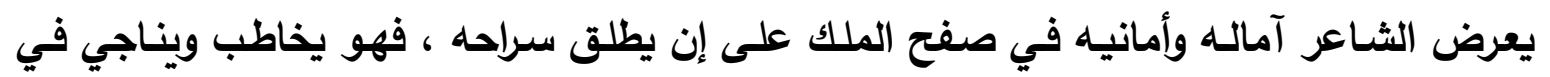

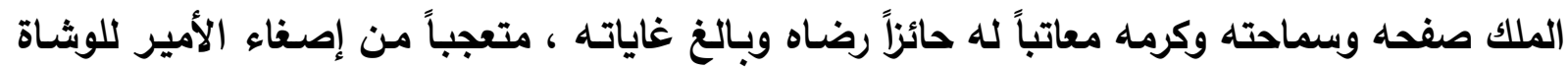

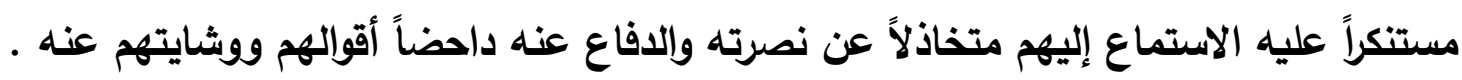

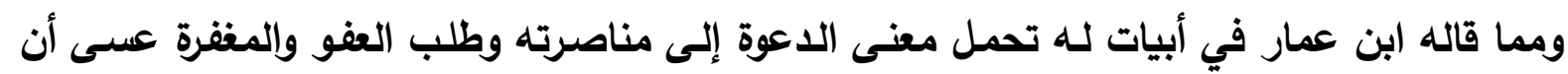
يعفو عنه المعتمد بعد أن استنفد كل طاقاته وتوسلاته بأبنائه قائلاً فيها (51) :

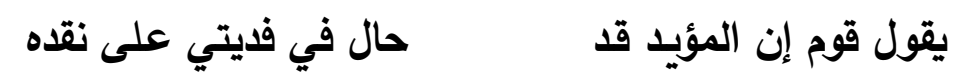

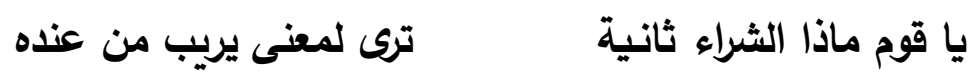

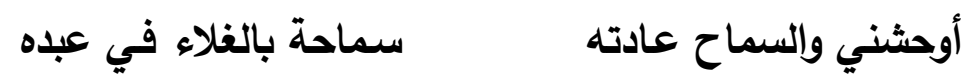

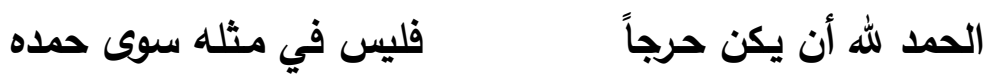

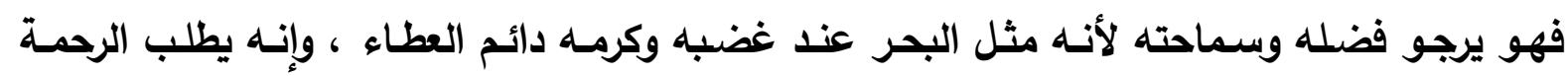
والعطاء حتى في حالة الغضب والسخط وعدم الرضا قائلاً

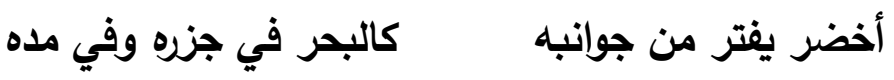

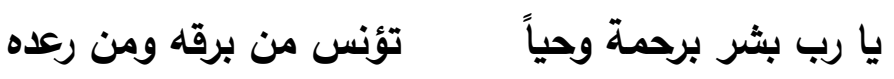

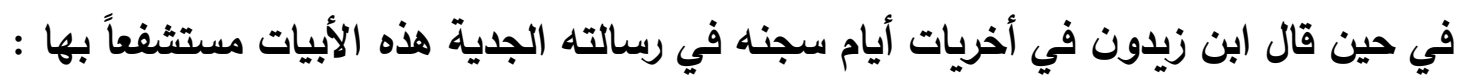

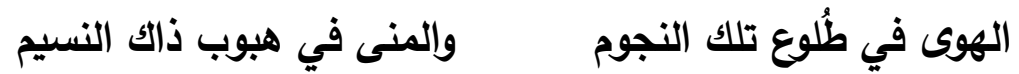

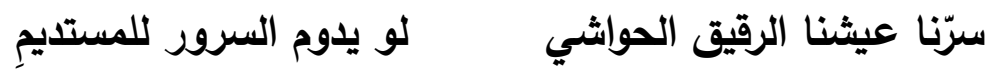
بوَأ الله "جهوراً" أشرف السو دد في السروِ وإللبابِ الصميمٍ

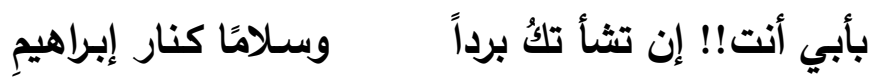

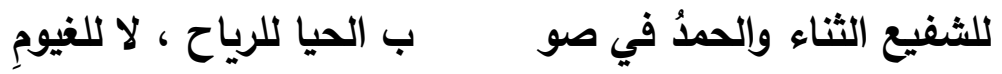

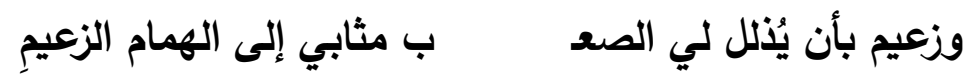

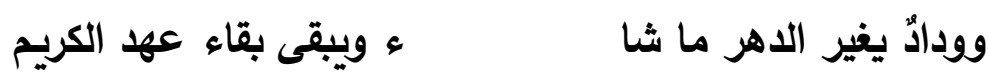

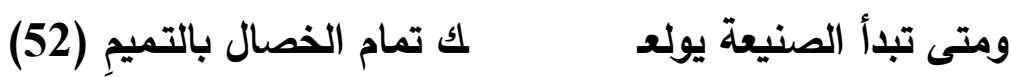


مقدمة غزلية للشاعر يبدؤها بألفاظ الطبيعة إذ " يتجها الإنسان إلى عرض عدة موضوعات محاولاً

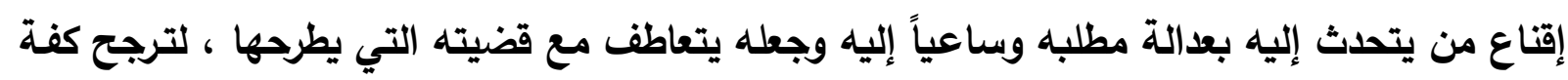

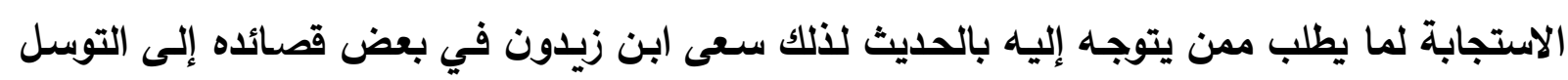

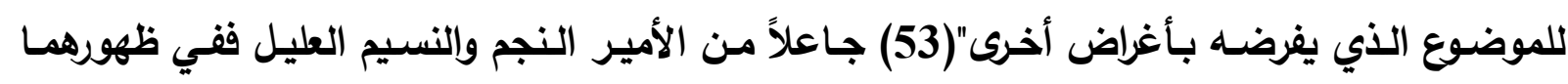

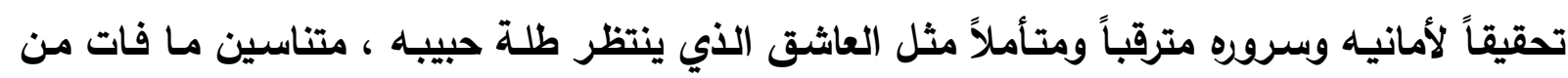

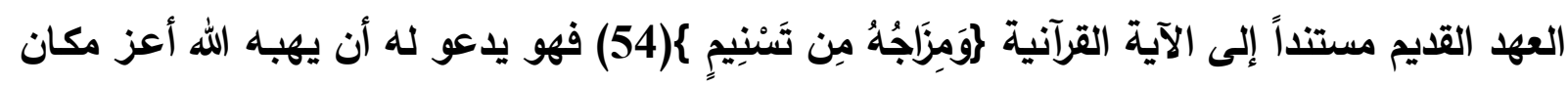

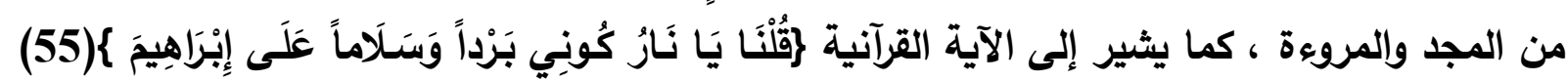

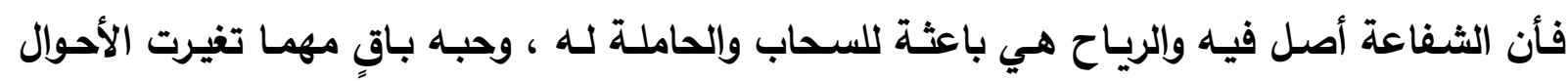

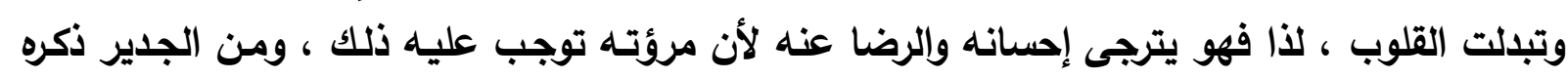

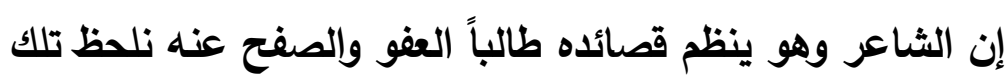

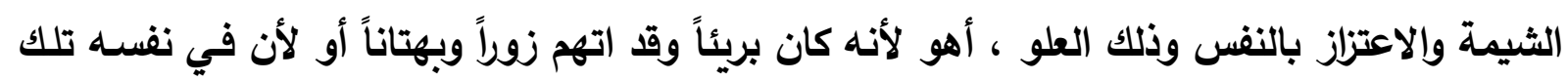

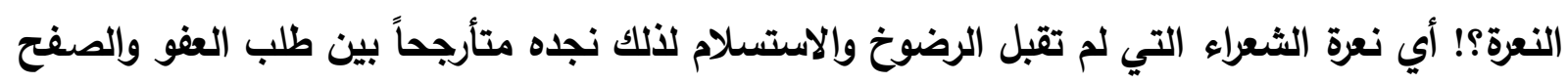

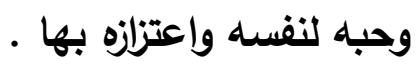

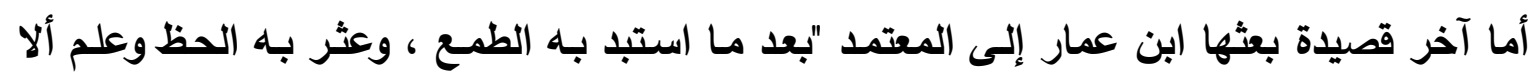

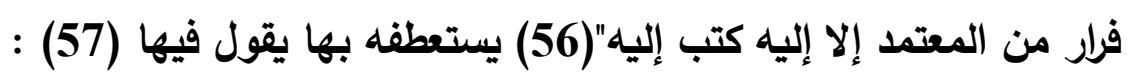
وعذرك إن عاقبت أجلي وأوضح فأنت إلى الأدنى من الله أجنح عداتي وأن اثنوا علي وأفصحوا سوى أن ذنبي واضح متصحح

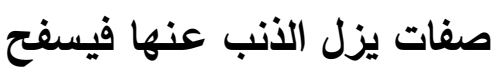
يخوض عدوي اليوم فيه ويمرح سجاياك إن عافيت أندى وأسمح وإن كان بين الخطتين مزيـة

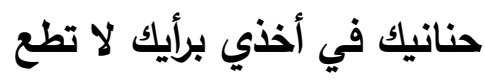

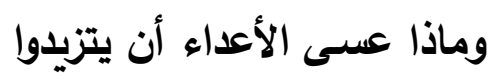
نعم لي ذنب غير أن لحلمه وإن رجائي أن عندك غيرما

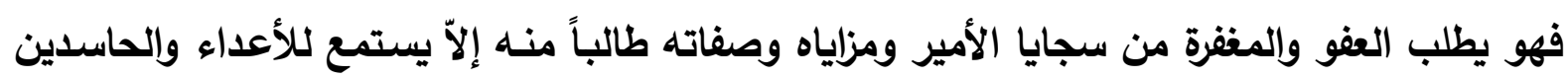

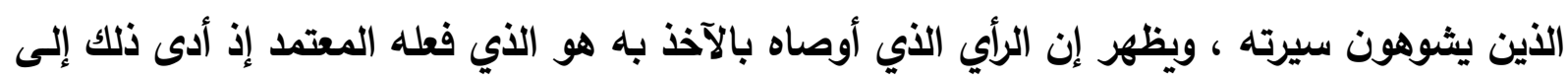

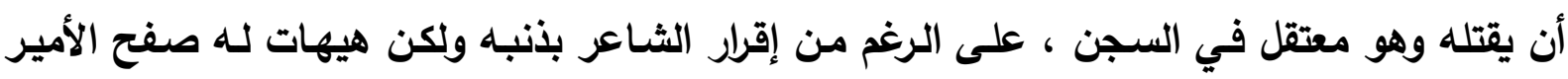

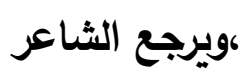
بالأمير ويذكره بما كان يحمله له من محبة وخدمة سابقة يقول فيها :

يكران في ليل الخطايا فيصبح

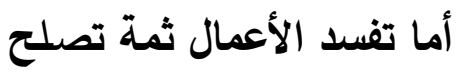
له نحو روح الله باب مفتح ولم لا وقد أسلفت وداً وخدمة

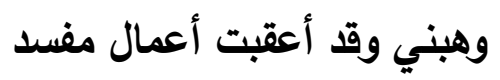
أقلني بما بيني وبينك من رضى 
وكأن ابن عمار يطلب مغفرته على أن يصحح أخطاءه وأعماله المشينة ولا يلتفت إلى أقوال الوشـاة

بهبة رحمي منك تمحو وتمصح

فكل إناء بالذي فيه يرشتح

إذا تبت لا انفك آسو وأجرح

أشاروا تجاهي بالشمات وصرحوا

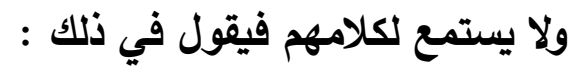

وعف على آثار جرم جنيته

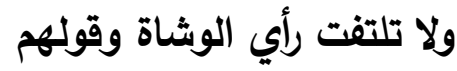

وما ذاك إلا ما علمت فإنتي

تخيلتهم لا در لله درهم

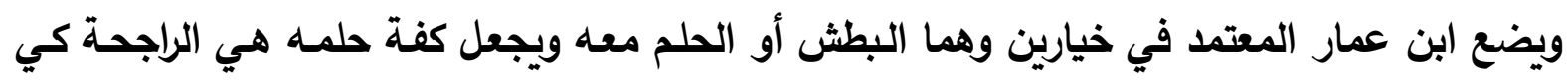

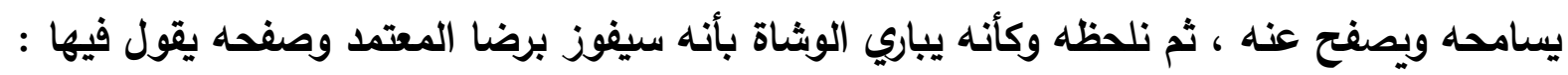

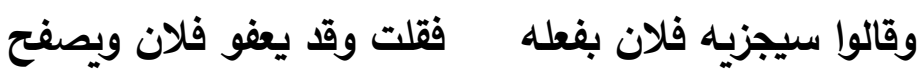

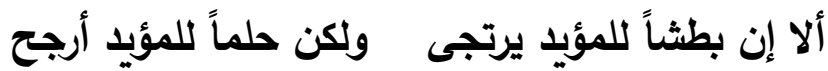

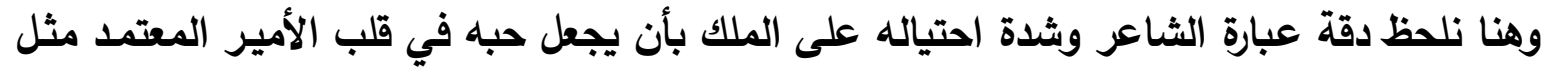

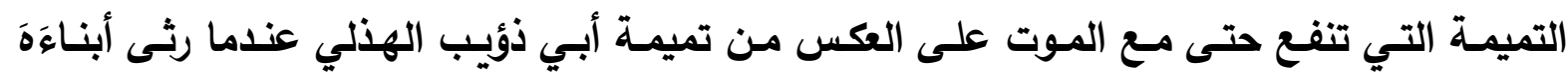
الخمسة قائلاً :

وإذا المنية أنشبت أظفارها الفيت كل تميمة لا تنفع (58)

وهذه التميمة نفسها التي أثار إليها الثاعر ابن عمار في اعتذاريته للمعتمد قائلاً :

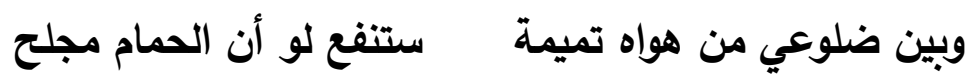

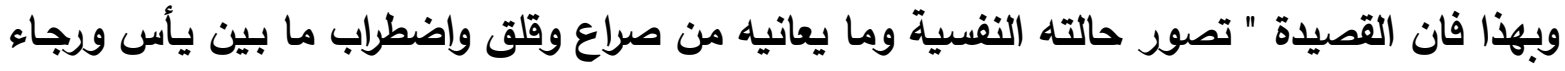

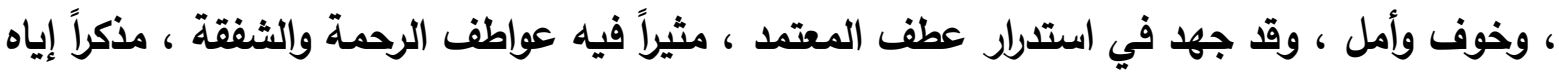

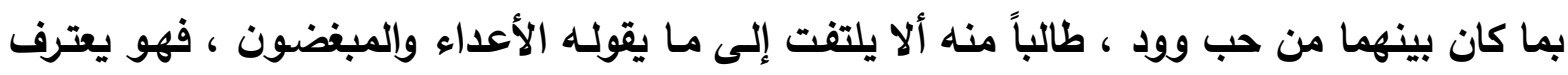

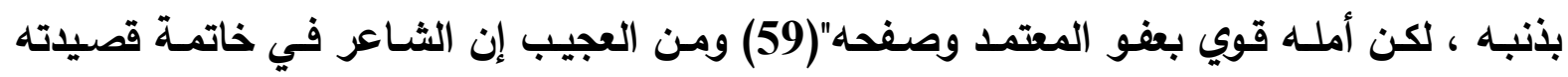

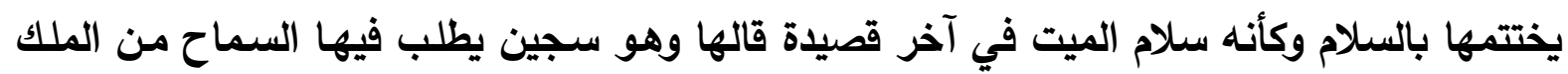

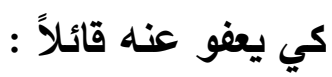

سلام عليه كيف دار به الهوى إلي فيدنو أو علي فينزح

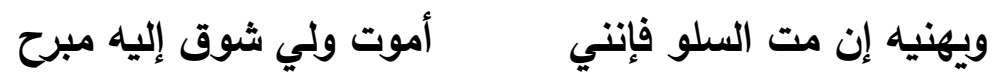

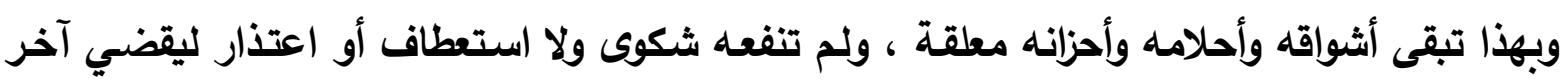

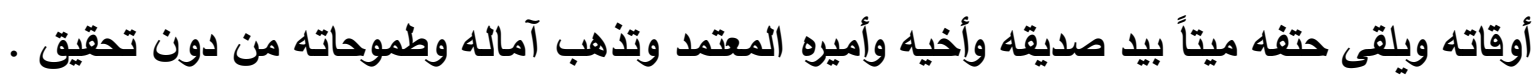


نستثف من مخاطبة الثاعر الوزير ابن زيدون العتاب واللوم وطلب الصفح والعفو من تهمة ألصقت

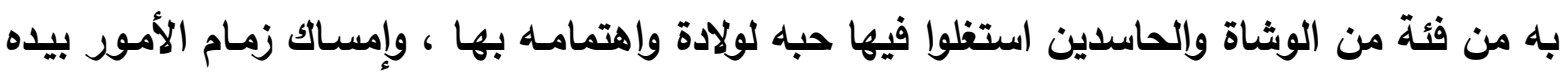

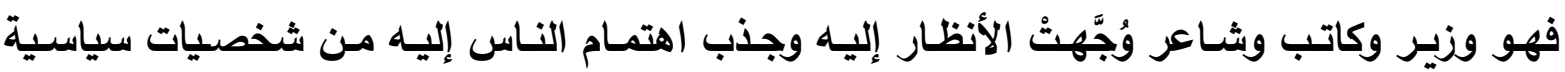

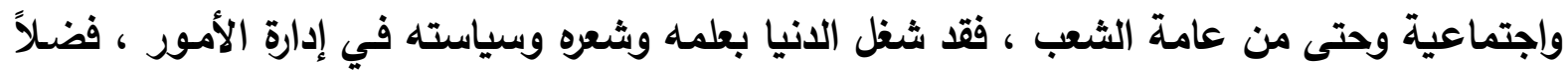

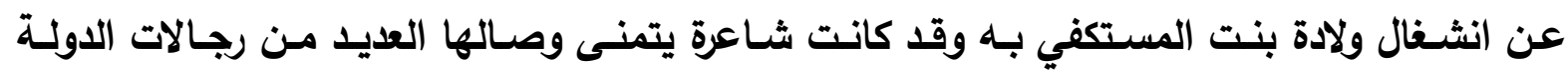

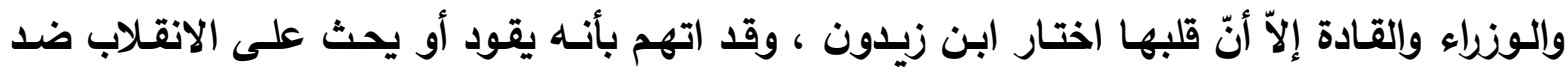

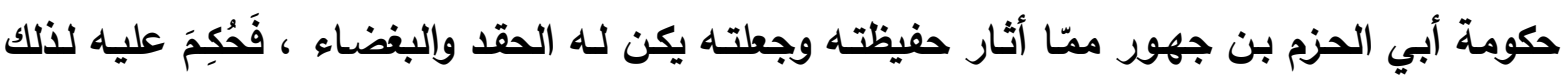

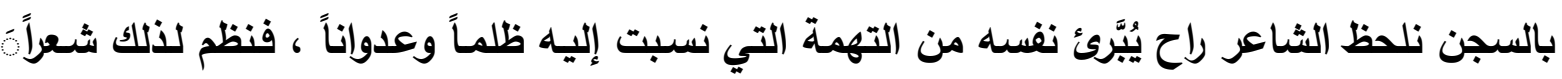
وهو في السجن يُفَُُّ هذه الأقوال الحاقدة ، راجياً أن يشمله برحمته نفه وصفحه ولكن لم يجبه ابن جهور

إن تثبيهات الثـاعر التي جاء بها من الطبيعة تمثل معنى العلو والسمو والثجاعة والمرووة

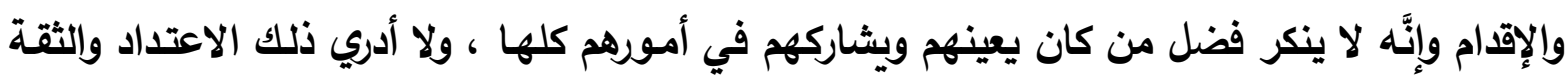

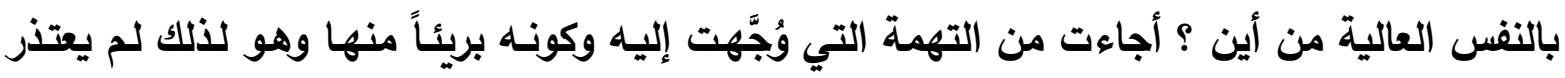

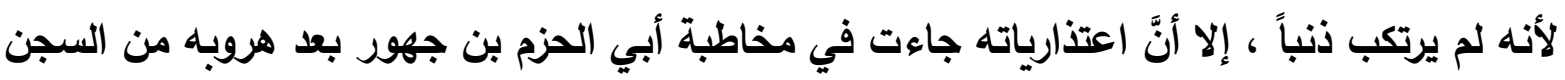

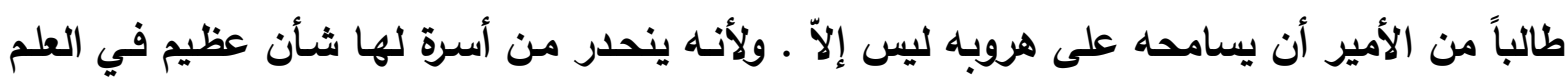

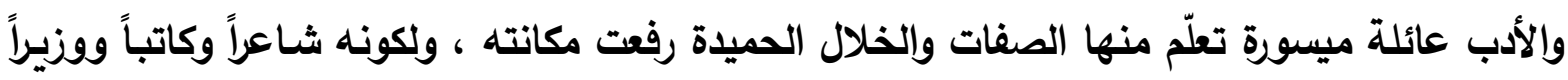

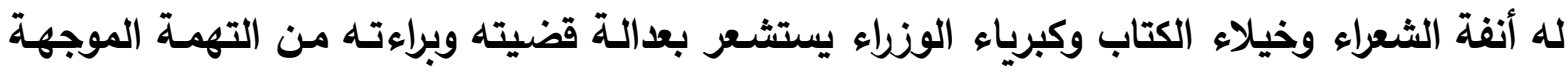

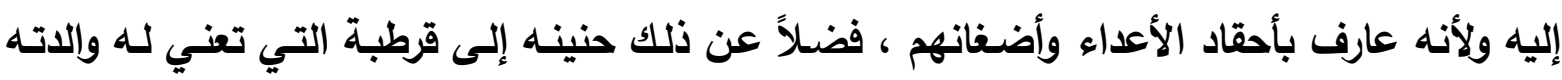

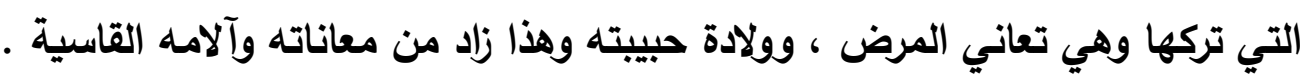

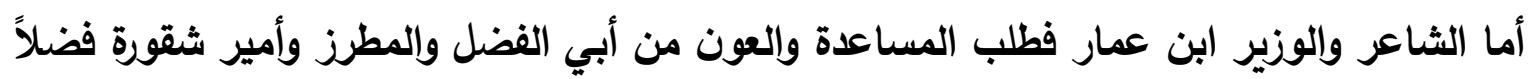

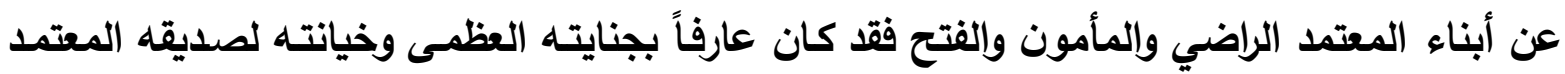

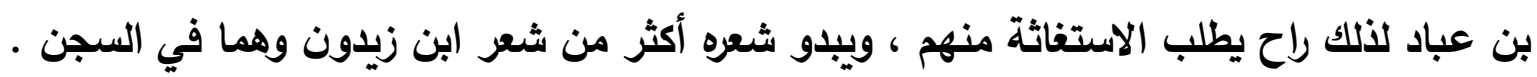

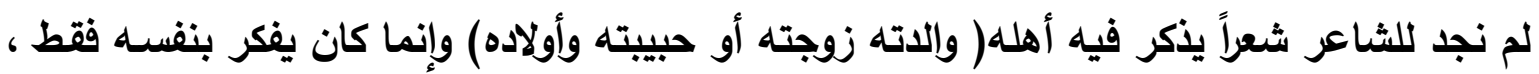
وكيف يتمكن من التخلص من السجن من دون أن يذكر أحداً ، تلاشي القيم والمعايير واللاهدفية

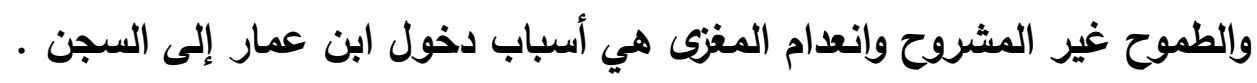

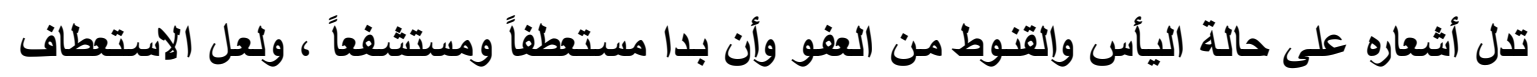

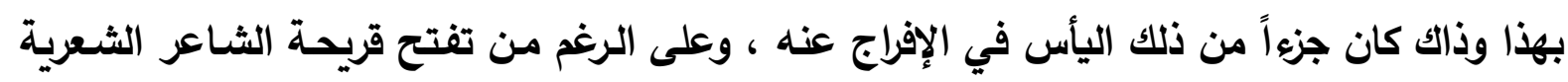

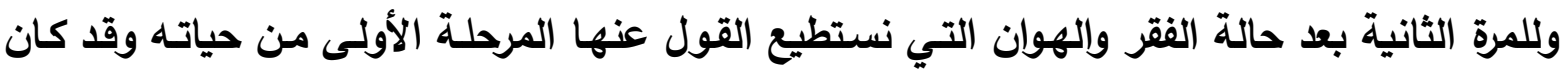

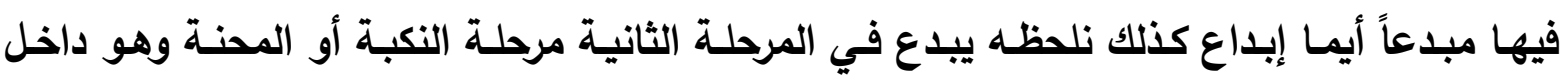


قضبان السجن ، ولهذا يمكنتا القول إن قمة شعره تتأرجح بين مرحلتين الأولى عندما كان يطلب ود

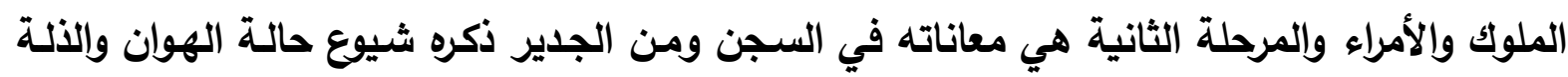
في ثنايا شعره وهو سجين .

قائمة الهوامش

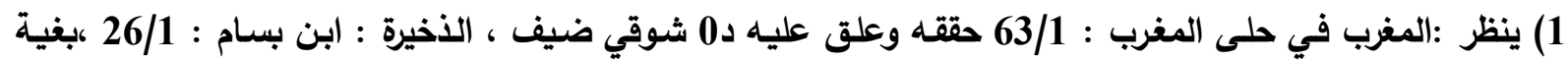

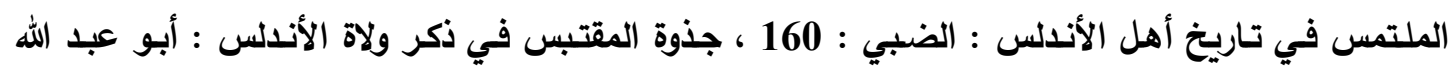

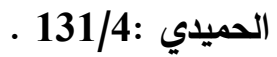

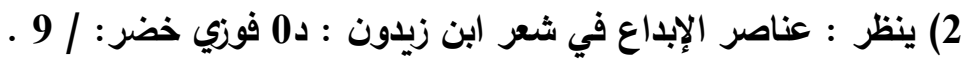

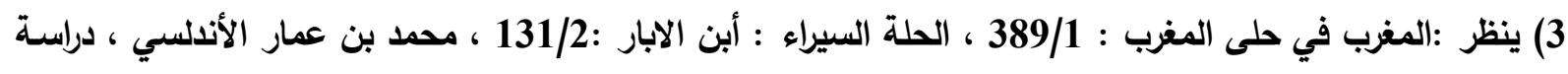

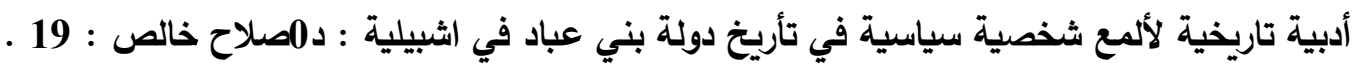
4) ينظر : المتتد بن عباد : علي أدهم : 99 : 99

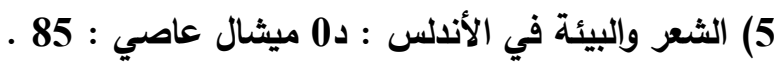
6) ديوان ابن زيدون ورسائله : 354 ـ

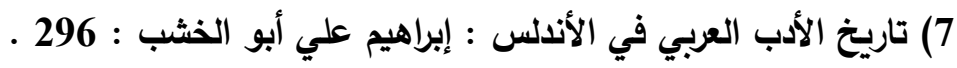

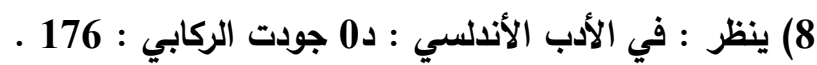

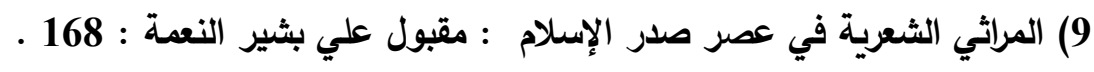

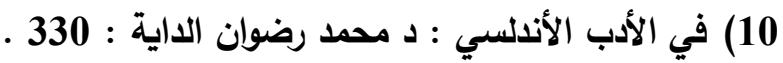

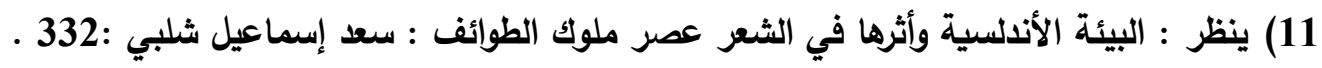




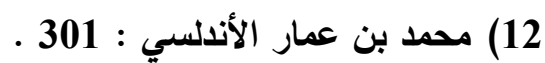
13) ديوان (ابن زيدون : دراسة وتهذيب : عبد الله سنده : 40 : 40

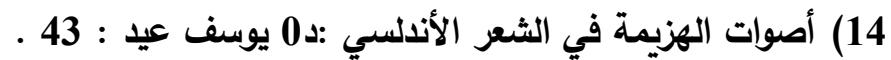
15) ينظر : شعر الأسر والسجون في عصر ما قبل الإسلام ، دراسة وتحليل :د0 محمد فتاح عبيد ، مجلة القادسية،

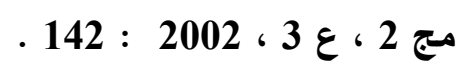

16) ينظر : أدب السجون : نزيه أبو نضال : 222 ـ 202

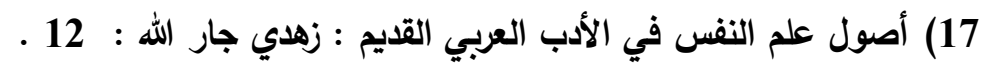

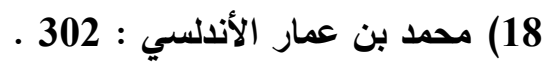

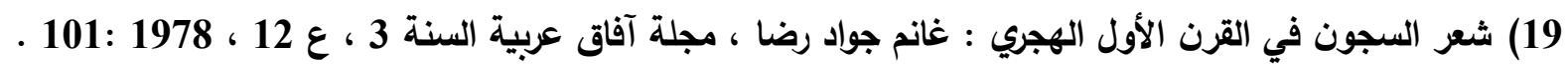

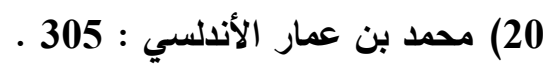

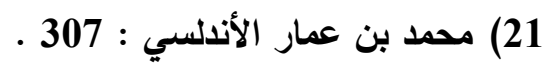

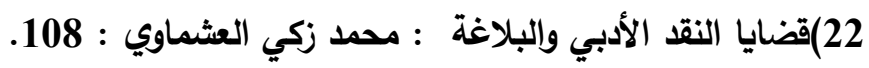

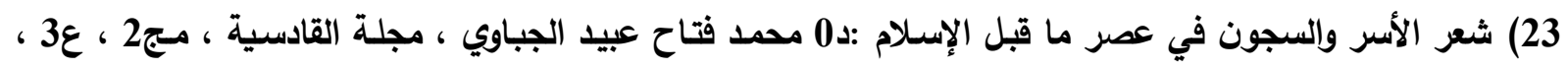
. 139 : 2002

24) ينظر : عصر ابن زيدون :د0 جمعة شيخة : 271 : 202

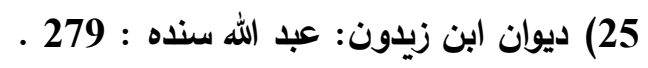

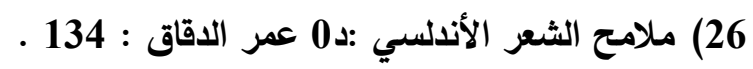

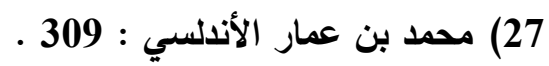

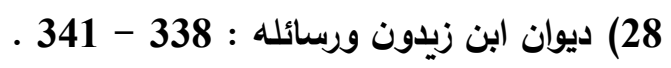

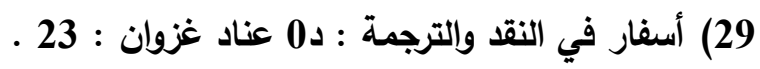

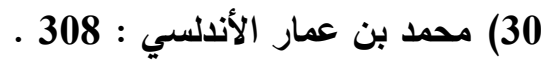

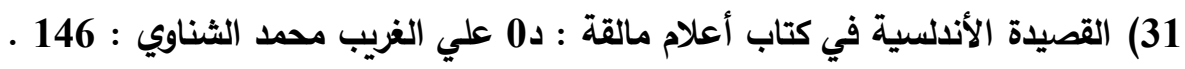

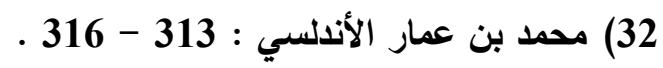

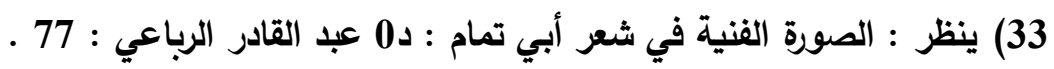

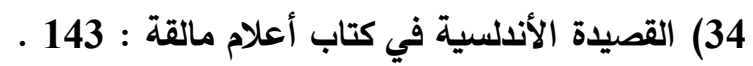

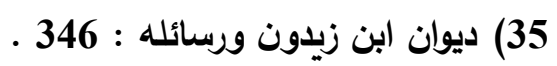

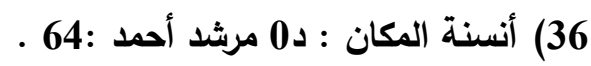

37) ينظر : دراسات في الثعر الأندلبي : 177 : 178 ـ

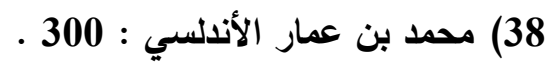

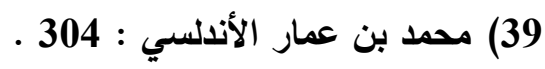

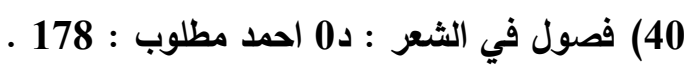

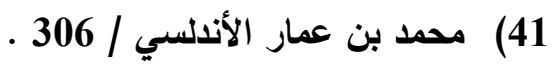

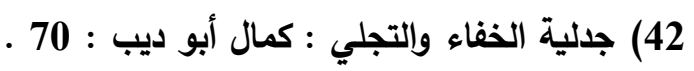

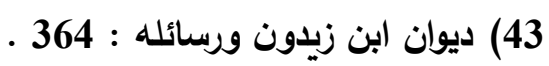


44) شعرنا الحديث...إلى أين ؟ غالي شكري :201 - 202 ـ

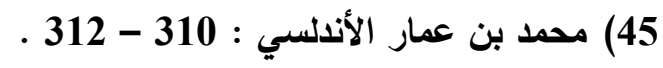
46) محمد بن عمار الأندلسي : 291 - 292 ـ

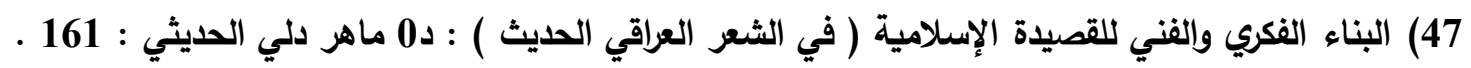
48) ينظر : عصر الاول والإمارات (الأندلس) د0 شوقي ضيف : 196

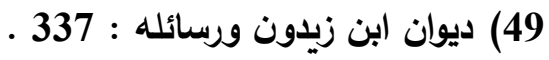
50) مظاهر الجرأة في الثعر الأندلسي :د 0 علدي مطثر نعيمة ، أطروحة دكتوراه ، جامعة البصرة ، كلية التربية ، 192: 2009

51) محمد بن عمار الأندلسي : 318-317 ـ

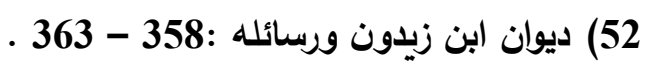
53) عناصر الإبداع الفني في شعر ابن زيدون : 46 ـ 452

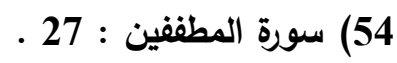
. 69 : 65 56) دراسات في الثعر الأندلسي : 180 : 189

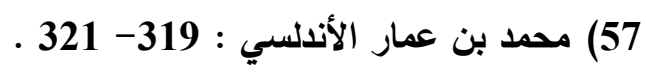

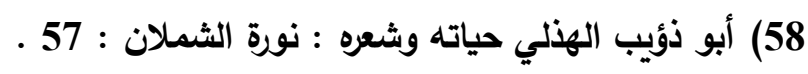

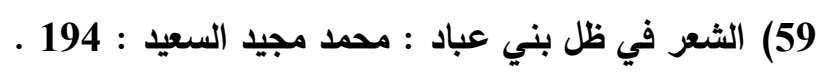
قائمة المصادر والمراجع : مديد القران الكريم

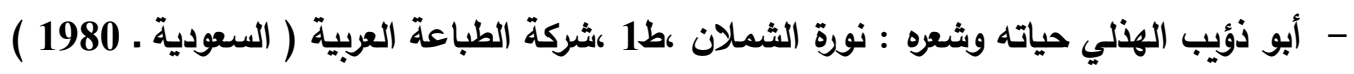

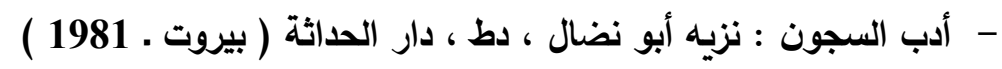

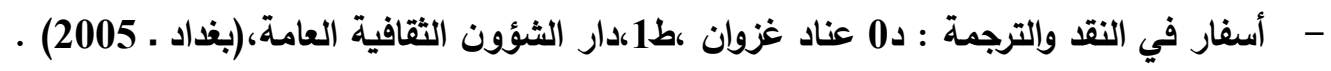

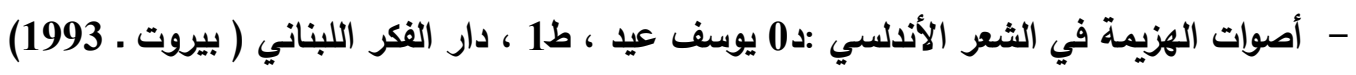

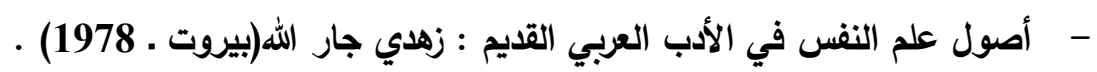

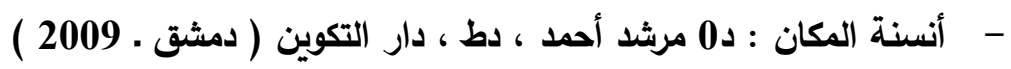

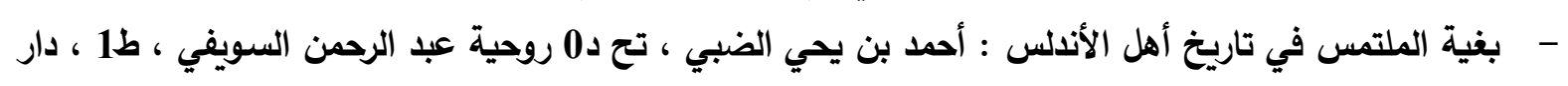

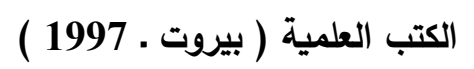
- - البناء الفكري والفني للقصيدة الإسلامية ( في الثعر العراقي الحديث ) : د0 م ماهر دلي الحديثي : ، دار الثئون

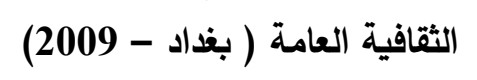

- البيئة الأندلسية وأثرها في الثـعر عصر ملوك الطوائف : سعد إسماعيل شلبي ، مطبعة نهضـة (القاهرة (1978

- - تاريخ الأدب العببي في الأندلس : إبراهيم علي أبو الخثب ، دار الفكر العببي ، مطبعة المدني ( القاهرة ـ دت ) 
جليـة الخفاء والتجلي : ، دراسـات بنيويـة في الثـعر : كمـال أبو ديب ، ط1 ، دار العلم للملايين ( بيروت -

جذوة المقتبس في ذكر ولاة الأندلس : لأبي عبد الله الحميدي ، قدم لله وضبطه وشرحه ووضع فهارسه د0 صلاح

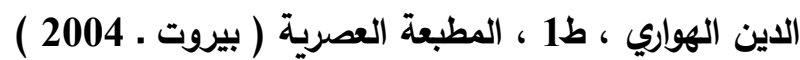

- - الحلة السيراء : (بن الأبار ، حققه وعلق حواشيه د0 حسين مؤنس ، ط2 ، دار المعارف ( القاهرة -1985 )

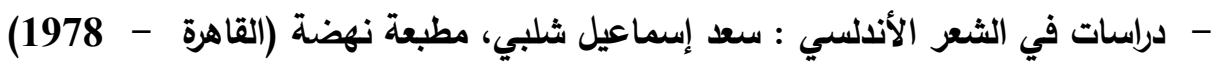

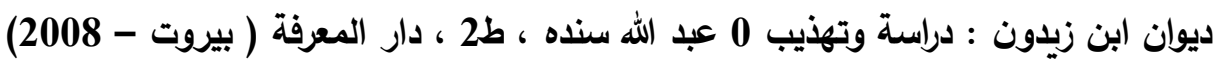

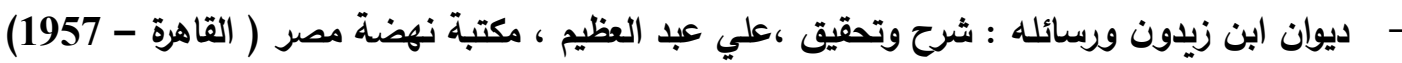

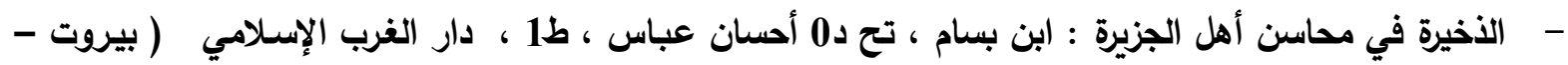

- - الثعر في ظل بني عباد : محمد مجيد السعيد ، ط1 ، مطبعة النعمان ( النجف ـ 1972)

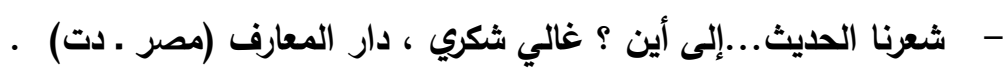

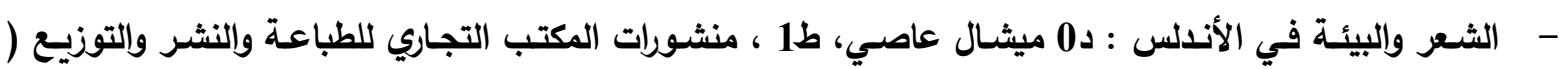
بيروت - 1970

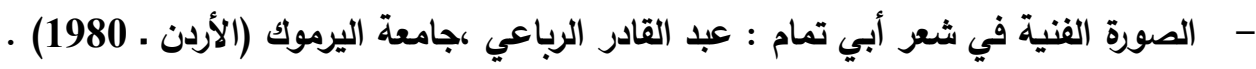
- عناصر الإبداع في شعر ابن زيلدون : د0 فوزي خضر ، مؤسسة جائزة عبد العزيز البابطين ( الكويت ـ 2004) .

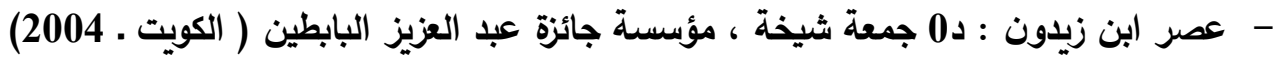

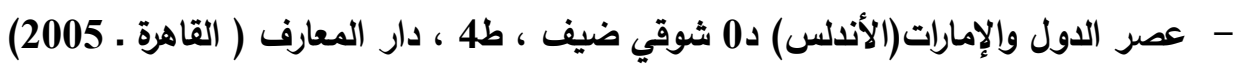
- فصول في الثعر : د0 أحمد مطلوب ، مطبعة المجمع العلمي ( بغداد ـ 1999) .

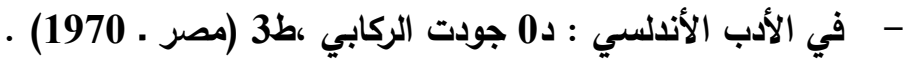

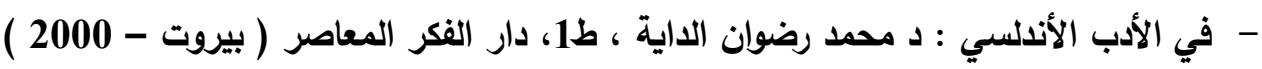

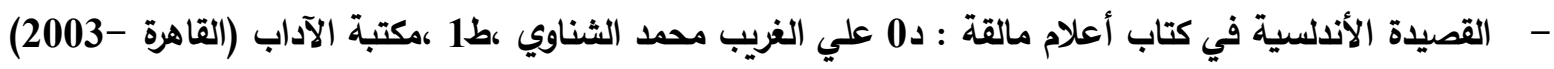

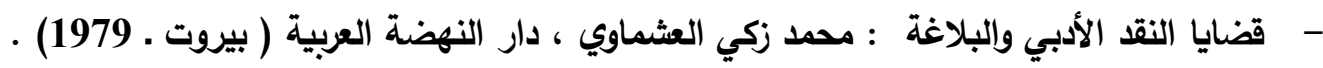

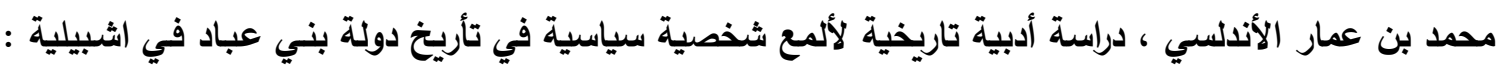

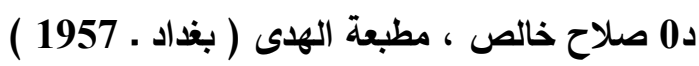

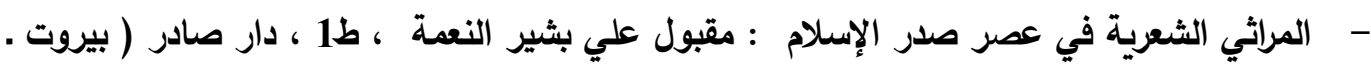

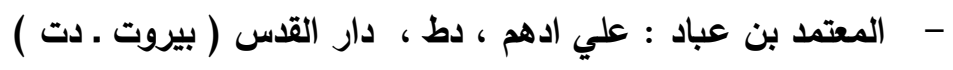

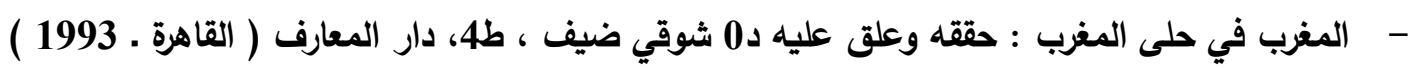

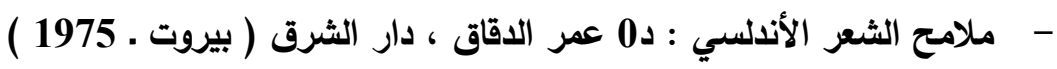
الاوريات

- شعر الأسر والسجون في عصر ما قبل الإسلام ، دراسة وتحليل :د0 محمد فتاح عبيد ، مجلة القادسية، مـج 2 ، . 2002 ، 3 ع

- - شعر السجون في القرن الأول الهجري : غانم جواد رضا ، مجلة آفاق عربية السنة 3 ، ع 12 ، 1978 . 
محور الأول المؤتمر اللغة العربية المؤتمر العلمي الرابع لكلية التربية / جامعة واسط

$$
\text { الرسائل والأطاريح }
$$

- مظاهر الجرأة في الثعر الأندلسي :د0علي مطثر نعيمة ، أطروحة دكتوراه ، جامعة البصرة ، كلية التربية ، 